\title{
Tectonics of the Simplon massif and Lepontine gneiss dome: deformation structures due to collision between the underthrusting European plate and the Adriatic indenter
}

\author{
Albrecht Steck
}

Key words: Alpine tectonics, Simplon massif, nappe tectonics, transpression, continental collision

\begin{abstract}
This study presents a review of published geological data, combined with original observations on the tectonics of the Simplon massif and the Lepontine gneiss dome in the Western Alps. New observations concern the geometry of the Oligocene Vanzone back fold, formed under amphibolite facies conditions, and of its root between Domodossola and Locarno, which is cut at an acute angle by the Miocene, epi- to anchizonal, dextral Centovalli strike-slip fault. The structures of the Simplon massif result from collision over $50 \mathrm{Ma}$ between two plate boundaries with a different geometry: the underthrusted European plate and the Adriatic indenter. Detailed mapping and analysis of a complex structural interference pattern, combined with observations on the metamorphic grade of the superimposed structures and radiometric data, allow a kinematic model to be developed for this zone of oblique continental collision. The following main Alpine tectonic phases and structures may be distinguished:
\end{abstract}

1. NW-directed nappe emplacement, starting in the Early Eocene ( $50 \mathrm{Ma})$;

2. W, SW and S-verging transverse folds;

3. transpressional movements on the dextral Simplon ductile shear zone since $\sim 32 \mathrm{Ma}$;

4. formation of the Bergell - Vanzone backfolds and of the southern steep belt during the Oligocene, emplacement of the mantle derived 31-29 Ma Bergell and Biella granodiorites and porphyritic andesites as well as intrusions of 29-25 Ma crustal aplites and pegmatites;

5. formation of the dextral discrete Rhone-Simplon line and the Centovalli line during the Miocene, accompanied by the pull-apart development of the Lepontine gneiss dome - Dent Blanche (Valpelline) depression.

It is suggested that movements of shortening in fan shaped NW,W and SW directions accompanied the more regular NW- to WNW-directed displacement of the Adriatic indenter during continental collision.
RESUME

Cette étude représente une revue de données géologiques publiées, complétées par des observations originales sur la tectonique du massif du Simplon et du dôme de gneiss du Lépontin. De nouvelles observations sont rapportées sur la géométrie du rétro-pli de Vanzone, formé à l'Oligocène sous des conditions du faciès amphibolite et sur sa racine située entre Domodossola et Locarno, où elle est coupée avec un angle aigu par le décrochement dextre, epi- et anchi-zonale de la faille du Centovalli, datée du Miocène. Les structures du massif du Simplon résultent de la collision de la plaque européenne sous-charriée et de l'éperon de la plaque adriatique, depuis $50 \mathrm{Ma}$. Ce sont deux bordures de plaques avec une géométrie très différente. Des levés géologiques détaillés et l'analyse des structures superposées, combinés avec des observations sur le degré du métamorphisme et des datations radiométriques, permettent de conclure sur un model cinématique de cette zone de collision continentale, de direction oblique et en transpression. Les phases et structures tectoniques alpines suivantes sont distinguées:

1. Dès l'Eocène inférieur ( $50 \mathrm{Ma})$, mise en place des nappes, dans une direction NW.

2. Formation de plis transverses de vergence W-SW.

3. Mouvements transpressifs dans la large zone de cisaillement ductile et dextre du Simplon.

4. A l'Oligocène, formation des plis de rétrocharriage Bergell - Vanzone, verticalisation des racines, mise en place des intrusions du Bergell, de Biella et d'andésites porphyritiques d'origine mantélique datées de 31-29 Ma et intrusion d'aplites et de pegmatites, d'origine crustale datées de 29-25 Ma,

5. Au Miocene, formation des lignes tectoniques dextres Rhone-Simplon et des Centovalli, accompagnée dans une structure d'extension et de transpression, du soulèvement du dôme de gneiss du Lépontin et de l'abaissement de la dépression de la Dent Blanche (Valpelline).

Nous concluons que le poinçon adriatique s'est déplacé selon un chemin régulier de direction NW à WNW, accompagné des déformations de raccourcissement NW-SE, W-E et SW-NE.

\section{Introduction}

The Simplon massif and the Lepontine gneiss dome in the Central Alps represent one of the best studied zones of continental collision, which has been investigated for over a 150 years (e.g.
Studer 1851; Gerlach 1869; Schardt 1903; Schmidt \& Preiswerk 1905; Argand 1911,1916; Preiswerk et al.1934; Bearth 1956a \& b; Wieland 1966; Hunziker 1969; Hunziker \& Bearth 1969; Milnes 1973, 1974; Milnes et al. 1981; Frank 1983; Steck 1984, 1990; Merle et al. 1989; Lacassin 1989; Mancktelow 1985, 1990, 1992; 


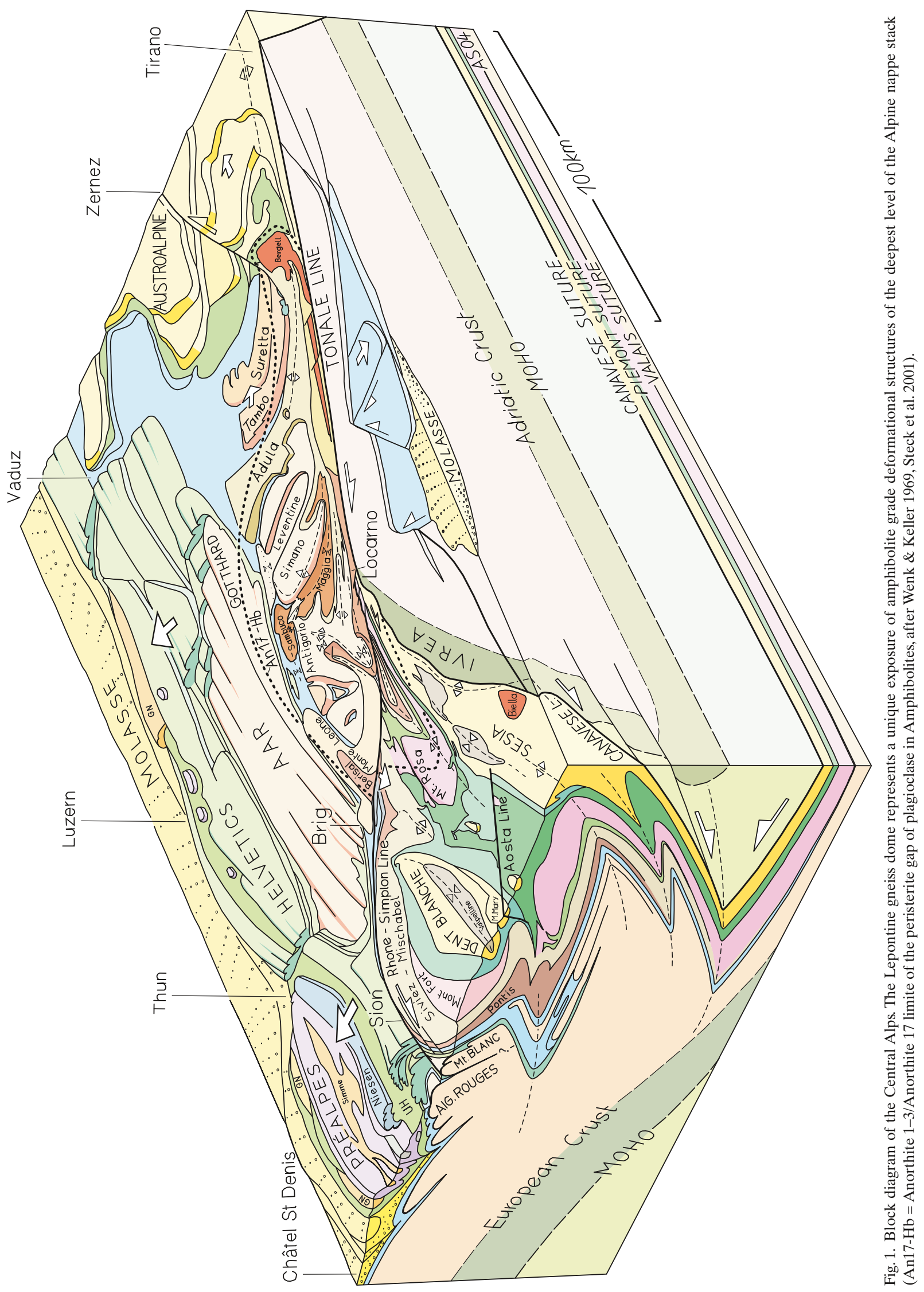


Steck \& Hunziker 1994; Steck et al. 1999, 2001; Engi et al. 2001; Keller et al., 2005; Handy \& Oberhänsli, 2004; Schmid et al. 2004; Maxelon \& Mancktelow 2005; Handy et al. 2005; Konrad-Schmolke et al. 2006; Babist et al. 2007). The Simplon massif and the Lepontin gneiss dome represent a unique region in the western Alpine arc where deformational structures of its deepest level of the nappe stack are exposed (Plate 1, Fig. 1). The continuous outcrop conditions of the Central Alps allow a study of the rock-rheology, dependent change in structural style between a superficial, more rigid, orogenic lid and a deepseated, very ductile, tectonic stage of the Alps. The complexity of the fold and fault interference pattern in this zone of continental collision exposed in the Central Alps (Plate 1) results mainly from the following:

1. the different and complex geometry of the European plate boundary and the Adriatic indenter (Fig. 2); and

2. the change from greenschist facies to higher amphibolite facies grade of the synorogenic Barrovian metamorphism, implying a strong change with depth in the ductile properties of the deformed rocks.

Different models have recently been published to explain the complex structures and the tectono-metamorphic history of the Lepontine Alps, and these need to be discussed (Milnes 1974; Milnes et al. 1981; Steck, 1984, 1990; Steck \& Hunziker 1994; Grujic \& Mancktelow 1996; Steck 1998; Keller et al. 2005, 2006; Maxelon \& Mancktelow 2005). New observations are presented in the present work concerning the geometry, kinematics and metamorphism of the Vanzone back fold and the Centovalli line. The aim of this study is to review already published data, completed by new observations, and to suggest an updated model for the formation of this complex zone of continental collision exposed in the Simplon area.

\section{Geological setting}

The Simplon area is the region of Eurasia, where Schardt (1903), Schmidt \& Preiswerk (1905) and Argand (1911) discovered and proposed the model of the nappe structures of the Alps. This generalisation of the nappe structure model to an entire mountain range happened 36 years after the description of the Antigorio recumbent fold by Gerlach (1869), and over 20 years after the discovery of the Glarus thrust by Bertrand (1884). The geology of the Central Alps is illustrated in recent geological and tectonic maps (1:500'000) of Switzerland, published by the Federal Office for Water and Geology (2005) and in an overview map of the Alps by Schmid et al. (2004). More detailed tectonic maps in a scale of 1:100'000 have been compiled by Steck et al. $(1999,2001)$ and Berger \& Mercolli (2006). An updated structural map of the Central Alps is represented on Plate 1 and the main tectonic units of the Simplon region are listed on Table 1 (modified after Steck et al. 2001 and Berger \& Mercolli 2006). The Central Alps are composed of pre-Triassic, poly- and mono-cyclic crystalline basement units and their Alpine metamorphosed Mesozoic - Cenozoic sedimentary cover
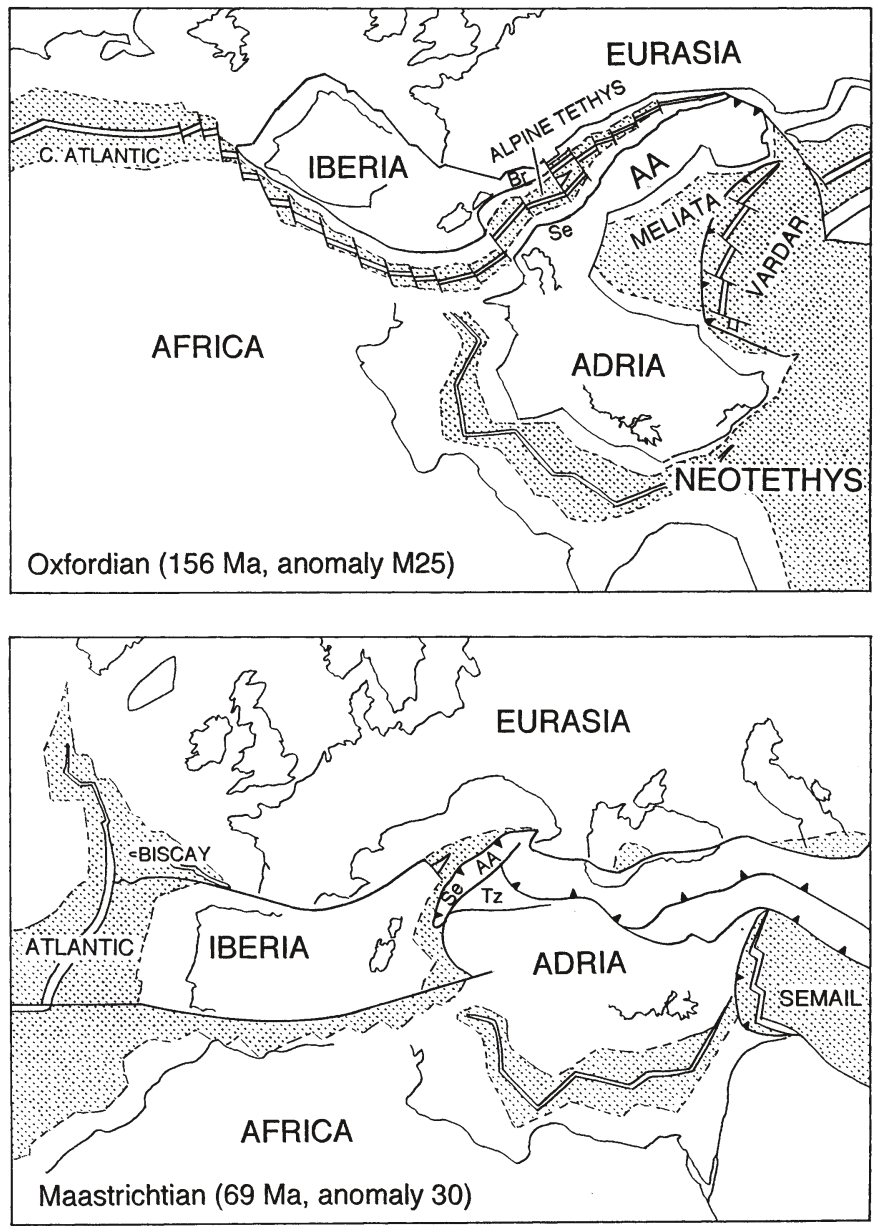

Fig. 2. Late Jurassic and Late Cretaceous plate geometry preceding the Tertiary collision of Eurasia, Iberia and Adria (modified after Stampfli et al. 2001; Bernoulli et al. 2003; Masson 2002; Schmid et al. 2004 and Masson et al. submitted; AA = Austroalpine, $\mathrm{Se}=$ Sesia zone, $\mathrm{Tz}=$ Tizia $)$. Note, that the Sesia zone (Se) has been overprinted by its high pressure metamorphism during a late Cretaceous phase of subduction (Babist et al. 2007; Hunziker et al. 1992; Ruffet et al. 1997; Rubatto et al. 1999).

series, Jurassic ophiolites of the Piemont basin (Alpine Tethys ocean) and Oligocene intrusives and volcanites, situated along the Periadriatic line. New units have been defined in the core of the Vanzone fold. The following units have been identified below the Antrona ophiolites (Plate 1, Fig. 3, 4):

- The Camughera unit composed of porphyritic granite gneisses, that are intrusive into metapelites and amphibolites,

- The Ruginenta unit, named after a village in the Antrona valley, comprising a basement of similar composition of the Camughera basement, which is stratigraphically overlain by the sediments of the Salarioli unit (Fig. 4; the "Salarioli mulde" of Bearth 1956b, consisting of Permo-Mesozoic sediments), composed of 10-180 m thick black graphiterich slates, sandstones and microconglomerates of probable Carboniferous age, followed by $1-10 \mathrm{~m}$ of Permo-Triassic 


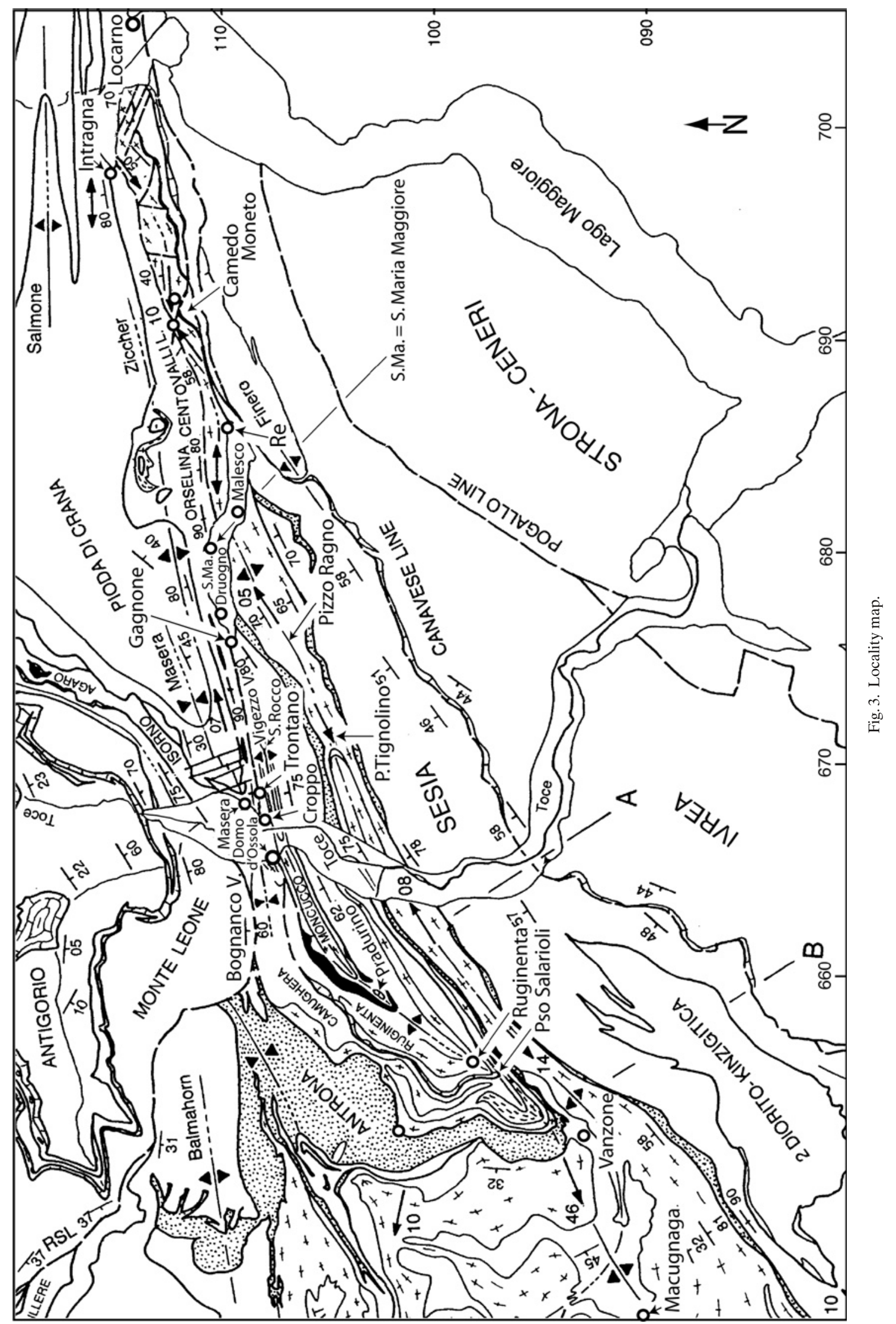




\section{SALARIOLI SEDIMENTS OF THE RUGINENTA UNIT}

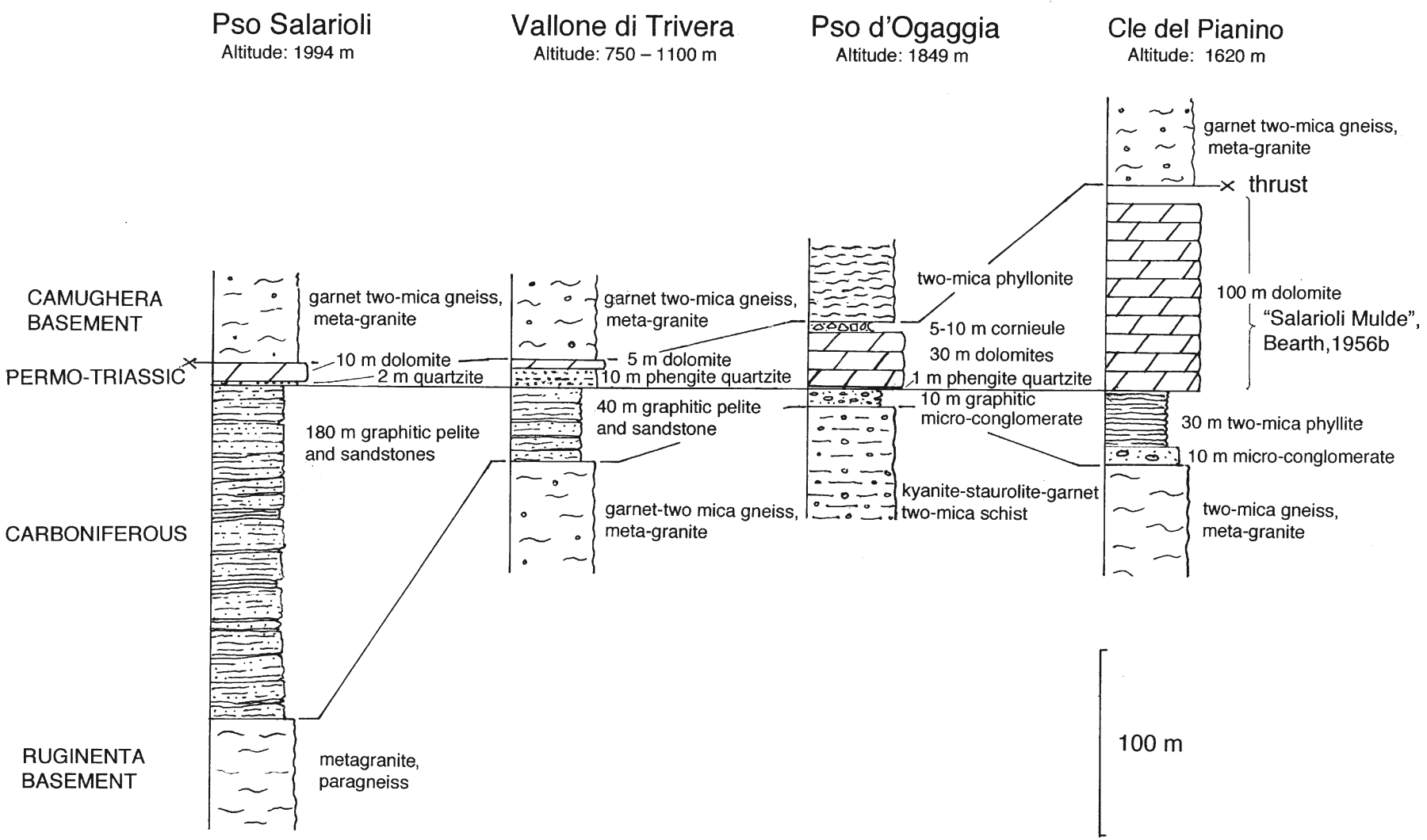

Fig. 4. Stratigraphy of the Carboniferous and Permo-Triassic sedimentary cover of the Ruginenta unit (Antrona valley). The name "Salarioli unit" is proposed for the whole Carboniferous - Triassic sedimentary sequence that lies in a normal stratigraphic position on the Ruginenta basement and forms a tectonic contact with the higher Camughera basement. Note that Bearth (1956b) and (Keller et al. 2005) used the term "Salarioli Mulde" for the Permo-Triassic sediments, that form, after their interpretation, a syncline (Mulde) in the Camughera unit.

phengitic quartzites and above this, boudins of 5-100 m thick Triassic dolomites with less than $10 \%$ of calcite and quartz. The contact to the higher Camughera gneisses is tectonic; on the Pso d'Ogaggia it is marked by several meters of cornieules.

- The Moncucco unit, within which we include the up to $400 \mathrm{~m}$ thick Moncucco peridotites, a sequence of metapelites, paragneisses, and amphibolites, an approximately $50 \mathrm{~m}$ wide fold hinge containing white siliceous marbles, outcropping at the Alpe Pradurino (Paleozoic or Mesozoic?; Bearth 1956b), and, in the core of the isoclinal Vanzone fold, the Moncucco porphyritic bi-mu-granite-gneiss, which is up to $700 \mathrm{~m}$ wide and has an age of $271 \pm 4,8 \mathrm{Ma}$, (Rb-Sr, Biggogero et al. 1981).

The distinction and correlation of the units in the Vanzone fold below the Antrona ophiolites is similar to the proposition of Milnes in Steck et al. (1979; Milnes \& Müller in Trümpy 1980): The Moncucco unit of this study is attributed by Milnes to the
Monte Leone nappe. The Rugginenta unit is named Moncucco unit and the Camughera unit of this study Camughera unit following the propositions of Bearth (1957). The two latter units correspond to the southern root of the Bernhard nappe of Argand (1911, 1916; Milnes in Steck et al. 1979). Keller et al. (2005) correlate their Camughera-Moncucco unit with the Monte Leone gneiss to the north of the Valle Bognanco. Bearth (1957) and Keller et al. (2005) propose that the Bernhard or Siviez-Mischabel nappe to the north of the Antrona ophiolites is a root less unit with no southern continuation in the Camughera-Moncucco units. The proposed separation of the Ruginenta and Moncucco units of this study is arbitrary and it cannot be ruled out that the two units actually belong to the same tectonic unit, as proposed by Argand (1911). It is also possible that the siliceous marbles of Alpe Pradurino represent a relict of Mesozoic sediments marking the boundary of these two tectonic units, as proposed on the geological and tectonic maps of Switzerland, 1:500'000 of the Federal Office for Water and Geology (2005). In this case, the Moncucco and Mon- 
dei peridotites belong to the upper unit, i.e. the newly defined Ruginenta unit. On Plate 1 and Fig. 1, the Camughera unit is correlated with the Siviez-Mischabel nappe, whereas the Ruginenta unit is correlated with the Pontis-Berisal nappe and the Moncucco unit with the Monte Leone nappe. This correlation is based largely on the tectonic position within the nappe pile (after unfolding of the last phases) and lithological affinity. It is also possible that a part of the Moncucco unit represents a lateral equivalent of the Bosco - Isorno - Orselina zone, which is characterised by numerous ultramafic bodies (Cima d'Agaro, Albogno etc., 5 ant 6 on Plate 1).

\section{The pre-Alpine Cretaceous paleogeography}

In this study we refer to investigations and models by Trümpy (1980), Stampfli et al. (2001); Bernoulli et al. (2003) and Schmid et al. (2004) for the Late Cretaceous paleogeography of the west-Mediterranean area, modified after Masson (2002; Masson et al. 2008; Fig. 2) prior to closure of the Piemont ocean (Alpine Tethys) and continental collision of Eurasia with the Adriatic indenter. The opening of the Piemont ocean is constrained by radiometric dating: The gabbroic blocks of the Gets nappe flysch have an age of $166 \pm 1 \mathrm{Ma}$ (U-Pb zircon age, Bill et al. 1997), the gabbros of the Zermatt-Saas Fee ophiolites ages of $164 \pm 2.7 \mathrm{Ma}$ (Allalin gabbro) and $163.5 \pm 1.8 \mathrm{Ma}$ (Mellichen gabbro, Rubatto et al.1996), the Antrona ophiolites an age of $163.1 \pm 2.4 \mathrm{Ma}, 158 \pm 17 \mathrm{Ma}$ and $155.6 \pm 2.1 \mathrm{Ma}$ and the Misox zone that of $161.0 \pm 3.9 \mathrm{Ma}$ (Liati et al. 2005). These ages suggest progressive opening of the Piemont ocean, from the Middle to the Late Jurassic and from S to N. A Cretaceous $\mathrm{U}-\mathrm{Pb}$ age of $93.4 \pm 1.7 \mathrm{Ma}$ of magmatic zircons has been found by Liati \& Froitzheim (2006) in an eclogitic metabasite of their newly defined Balma unit in the roof of the Monte Rosa nappe ( $2 \mathrm{~km}$ to the $\mathrm{E}$ of Point 2 on Figure 7). The authors suggest that the Balma unit belongs to the Valais basin. In this study it is suggested that either the dated metabasites belong to the Zermatt - Saas Fee ophiolites or to the Furggzone. The age testify in the first case of a Cretaceous continuation of basaltic magmatism in the Piemont ocean or represents in the second case basaltic dikes intruding the Paleozoic to upper Jurassic Furgg sediments as observed at the passo della Preja (Steck et al. 2001). It is also important to note that the gabbro intrusions, within the ophiolites of the Versoyen zone are in tectonic contact with the Cretaceous Sion-Courmayeur-Tarantaise flysch unit and have been dated at $334 \pm 4$ Ma (SHRIMP U-Pb age on zircon, Bussy et al. 2005; Masson et al. 2008). The Versoyen ophiolites represent the Paleozoic basement that is stratigraphically overlain by the Triassic dolomites and Liassic calcschists of the Petit St. Bernhard tectonic unit. The Carboniferous Versoyen ophiolites and its Mesozoic sedimentary cover are together overprinted by an Alpine eclogite facies metamorphism (Bousquet et al. 2002) and form the newly defined Versoyen-Petit St. Bernhard unit (Masson et al. 2008). A wildflysch (Méchandeur Formation) with elements of the latter unit is exposed in the Versoyen valley on the tectonic contact between the $\mathrm{Pa}$ - leozoic ophiolites of the Versoyen-Petit St. Bernhard nappe on top and the Sion-Courmayeur-Tarantaise calcschist unit of the Valais zone below. This wildflysch is interpreted (Masson et al. 2008) as the youngest sediment of the Sion-CourmayeurTarantaise unit. This wildflysch may be a southern equivalent of the mélange of Visp (Visp wildflysch on Fig. 5; Masson 2002, 2006; Masson et al. 2008). The ophiolites from Visp (Valais, Switzerland) represent blocks and olistoliths in the polygenic Visp olistostrome (mélange, wildflysch, Masson 2002; ensemble du Furgguwald, Steck 1987; Visp wildflysch on Fig. 5). It follows that the Late Cretaceous (?) to Eocene Valais basin was an important marine wrench basin with a thick succession of Late Cretaceous (?) to Priabonian flyschoid sediments (calcschists or "Bündnerschiefer"), with Middle Jurassic ophiolites only in Eastern Switzerland, in the Misox zone (161.0 $\pm 3.9 \mathrm{Ma}$; Liati et al. 2005), and in the Ramosch zone of the Engadine window (Florineth \& Froitzheim 1994), where the Valais trench basin reaches the Piemont ocean with its oceanic crust (Trümpy 1980). In conclusion, the Late Cretaceous (?) to Priabonian Valais basin, of western Switzerland, was not the Cretaceous ocean with an oceanic crust, as proposed in classical and recent paleogeographic models of the Alps (Trümpy 1980; Froitzheim et al. 1996; Stampfli et al. 2001; Schmid et al. 2004). The root of the Sion-Courmayeur-Tarantaise flysch is situated in the Valais suture on the limit of the European (Helvetic) and Briançonnais domains (Plate 1, Fig. 1 \& Table 1). An other ophiolite sequence, composed of meta-peridotites, -gabbros and -basalts is associated with the continental rocks of the Moncucco and Bosco-Isorno-Orselina units, in the latter with carbonate sediments. The age of this ophiolites is unknown, probably Paleozic and/or Mesozoic. These units are rooting north of the Monte Leone gneiss and Sion-Courmayeur-Tarantaise flysch in the Valais suture (Table 1, Fig. 1 and Plate 1). The subduction, exhumation and accretion of the Sesia zone as a part of the Adriatic margin occurred in the Late Cretaceous before the closure of the Piemont ocean (Konrad-Schmolke et al. 2006; Handy et al. 2005; Babist et al. 2007). The Sesia high-pressure metamorphism was dated of 65-68 Ma (Hunziker et al. 1993; Duchène et al. 1997; Rubatto et al. 1998, 1999; Babist et al. 2007).

\section{Alpine continental collision and orogenic metamorphism}

Rock deformation and metamorphism are interdependent processes that characterise a zone of continental collision. Apart from composition the mechanisms of deformation depend on the pressure - temperature - time conditions, and the age of the deformational events may be constrained by radiometric dating of metamorphic minerals and synorogenic magmatic rocks. N-NW-directed fold nappes and thrusts are early Alpine structures related to continental collision (Fig. 5). These nappes have been formed by the detachment of the upper part of oceanic and continental crust of the Austro-alpine continental domain (Sesia zone), the Piemont oceanic crust, and the Briançonnais and European continental crust, during underthrusting to the SE below the Adriatic plate. These units were subducted 


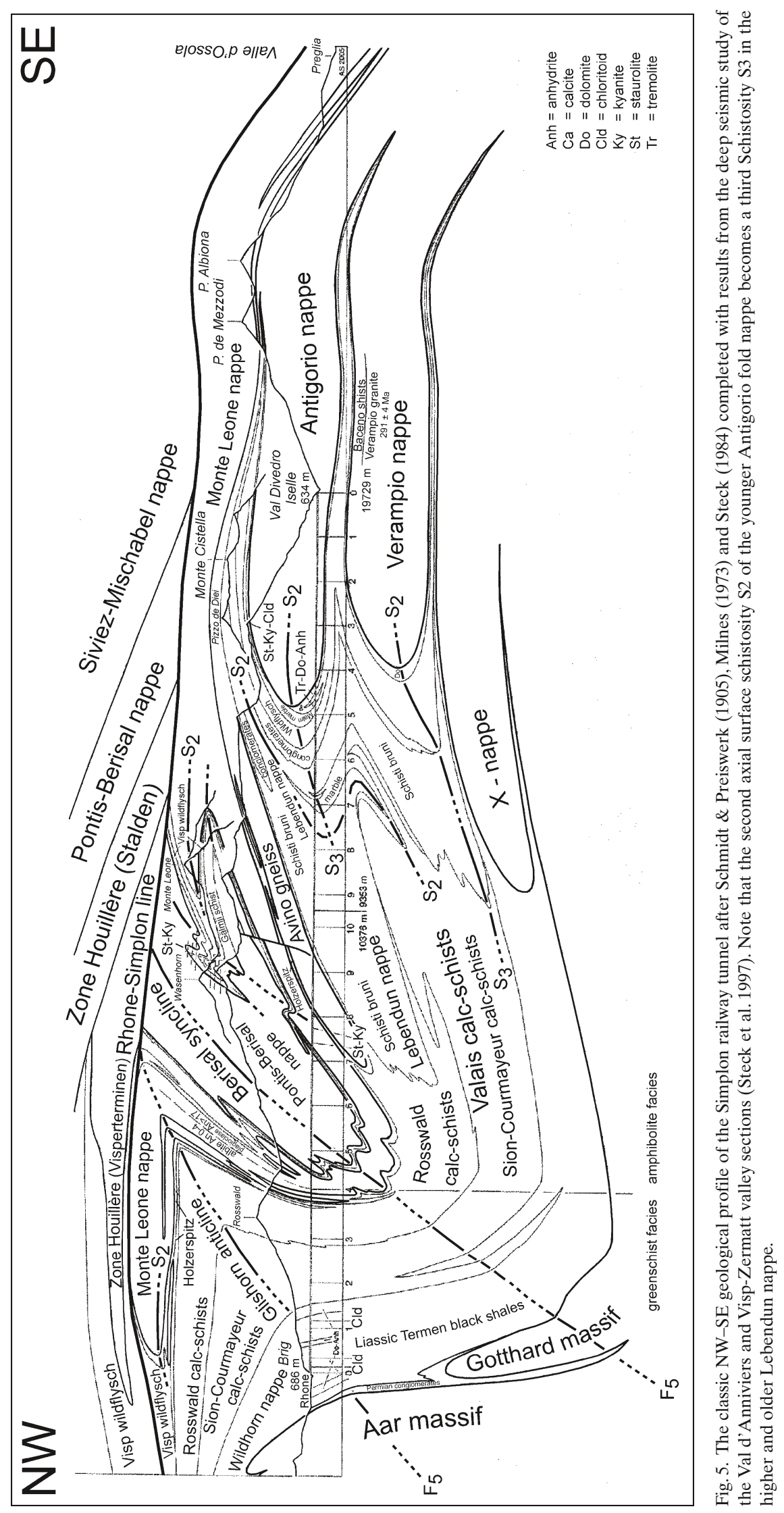

Tectonics of the Simplon massif and Lepontine gneiss dome 521 
Table 1. List of the Alpine tectonic units of the Simplon area represented on Plate 1, modified after Steck et al. (1999, 2001), Geologische Karte der Schweiz, 1:500'000 (2005); Berger \& Mercolli (2006).

\begin{tabular}{|c|c|c|c|c|c|c|}
\hline Domain & Simplon-W & \multirow{8}{*}{ 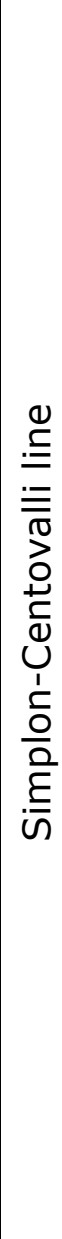 } & Simplon-E & Maggia valley & Ticino valley & \\
\hline Helvetic & & & $\begin{array}{c}\text { Aar-Gastern } \\
\text { Gotthard }\end{array}$ & $\begin{array}{c}\text { Aar } \\
\text { Gotthard }\end{array}$ & $\begin{array}{c}\text { Aar } \\
\text { Gotthard }\end{array}$ & \\
\hline Lower Penninic & $\begin{array}{l}\text { Moncucco - } \\
\text { Monte Leone }\end{array}$ & & $\begin{array}{c}\text { Verampio } \\
\text { Antigorio } \\
\text { Lebendun-Bombogno } \\
\text { Bosco-Isorno-Orselina } \\
\text { Monte Leone }\end{array}$ & \begin{tabular}{|c|} 
San Carlo \\
Antigoro \\
Mergoscia-Someo HP \\
Maggia \\
Lebendun \\
Bosco-Isorno-Orselina
\end{tabular} & $\begin{array}{c}\text { Leventina } \\
\text { Simano } \\
\text { Cimalunga-Adula HP } \\
\text { Bellinzona HP? }\end{array}$ & $\begin{array}{l}\searrow \\
\stackrel{0}{2} \\
\text { 늘 } \\
\text { ய }\end{array}$ \\
\hline Valais & Sion-Courmayeur (Valais) & & Sion-Courmayeur (Valais) & Valais units & Valais units HP & VS \\
\hline Middle Penninic & \begin{tabular}{|c|} 
Zone Houillère \\
Pontis-Ruginenta \\
Siviez-Mischabel-Camughera \\
Cimes Blanches-Frilihorn \\
Portjengrat-Furgg HP \\
Monte Rosa HP \\
\end{tabular} & & & & & 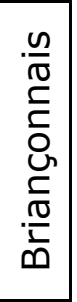 \\
\hline Upper Penninic & $\begin{array}{c}\text { Antrona HP } \\
\text { Zermatt-Saas Fee HP } \\
\text { Tsaté }\end{array}$ & & & & & 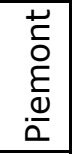 \\
\hline Austroalpine & Dent Blanche-Sesia HP & & & & & AA \\
\hline Southern Alps & $\begin{array}{c}\text { Canavese } \\
\text { Valpelline - 2DK } \\
\text { Ivrea } \\
\text { Strona-Ceneri }\end{array}$ & & & & & $\frac{\pi}{\frac{\pi}{2}}$ \\
\hline
\end{tabular}

to different depths before their detachment, extrusion and accretion in the Alpine orogenic belt. Eclogite facies mineral assemblages, with coesite in the Zermatt - Saas-Fee nappe, testify that in an early stage of subduction, some units reached a depth of over $90 \mathrm{~km}$ before their very rapid extrusion (Trommsdorff 1991; Reinecke 1998; Engi et al. 2001; 2004; Bucher et al. 2003) in a so-called tectonic accretionary channel (TAC), a term applied by Engi et al. (2001). Both the resultant structures and the mechanism of extrusion in this Early-Alpine tectonic accretionary channel are complex and still not well understood. The great volume of low-density serpentinites in the Zermatt - Saas-Fee zone may be responsible for an important support by buoyancy driven extrusion of this high-pressure unit. Two periods of high-pressure metamorphism have been dated in the transect of the Western Alps considered here: the Sesia zone metamorphism of Late Cretaceous age (Hunziker et al. 1992; Duchène et al. 1997; Ruffet et al.1997; Rubatto et al. 1999; Babist et al. 2007) and Alpine middle Eocene metamorphism of the ophiolitic Zermatt-Saas Fee and Antrona, the Monte
Rosa, Portjengrat and Cimalunga-Adula units dated 50-40 Ma (Becker 1993; Gebauer 1999; Amato et al. 1999; Engi et al.2001; Lapen et al. 2003; Mahlen et al. 2005). The whole Alpine nappe stack was then overprinted by a younger late Eocene Barrovian regional metamorphism. This Alpine nappe stack consists of (from top to bottom) the Austroalpine Dent Blanche nappe, the Upper Penninic ophiolitic Tsaté, Zermatt-Saas Fee and Antrona nappes of Piemont ocean origin, the Middle Penninic continental Monte Rosa, Portjengrat-Furgg, Cimes BlanchesFrilihorn, Siviez-Mischabel, Pontis-Berisal and Zone Houillère nappes of the Briançonnais domain, and the Lower Penninic Cretaceous - Priabonian Valais calcschists, the continental Monte Leone, Bosco-Isorno-Orselina (with ophiolites), Lebendun-Bombogno, Maggia, Someo-Cimalunga-Adula, Antigorio-Pioda di Crana-Simano, Verampio, Leventina-Lucomagno nappes and the Helvetic Gotthard, Tavetsch, Aar and Gastern gneiss folds and their sedimentary cover nappes (Plate 1, Fig. 1 and Table 1). The greenschist-facies metasediments of the Valais basin contain relicts of a blueschist-facies event related 
to an external Valais subduction zone (Bousquet et al. 2004; Oberhänsli \& Goffé 2004). The Monte Leone nappe contains 3T-polytype phengite relicts of a high-pressure metamorphism overprinted by the regional amphibolite-facies metamorphism (Hammerschmidt \& Frank 1991) and may belong to the same external Valais subduction zone. The temperature peak of the Barrovian regional metamorphism was dated by Hunziker et al. (1992) and Markley et al. (1998) with the Rb-Sr and ${ }^{40} \mathrm{Ar} /$ ${ }^{39} \mathrm{Ar}$ - methods on white mica at about 41 to $36 \mathrm{Ma}$ in the middle Penninic Siviez-Mischabel nappe. Younger ages in the centre of the Lepontine gneiss dome are interpreted as cooling ages, where amphibolite facies conditions lasted to $26 \mathrm{Ma}$ (Hurford 1986; Hunziker et al.1992; Steck and Hunziker 1994). A similar metamorphic history lasting from early eclogite facies to the younger Barrovian metamorphic phase is corroborated by U$\mathrm{Pb}$ monazite dating by Engi et al. (2001). The U-Pb monazite ages range in a W-E profile through the Monte Rosa nappe from 46-41 Ma (eclogite facies event) in the Macugnaga region, 41-34 Ma near Antrona, 33-26 Ma at Beura in the Ossola valley and 33-31 Ma in the Pizzo Tignolino-Pizzo Ragno region of the Vigezzo valley (Fig. 3). Peak amphibolite facies metamorphic conditions of $700{ }^{\circ} \mathrm{C}$ and $9.5 \mathrm{kbar}$ were reached in garnet-phengite-biotite-plagioclase-kyanite-staurolite mineral assemblages of the Camughera and Ruginenta units of the Antrona valley (Keller et al.2005). Furthermore secondary high temperature of $700{ }^{\circ} \mathrm{C}$ and low pressure of $7 \mathrm{kbar}$ conditions, indicated by sillimanite-staurolite assemblages, occur in the Ruginenta unit, $2-4 \mathrm{~km}$ to the W of Domodossola (Keller et al. 2005). The nearly isothermal pressure drop was assisted by the synmetamorphic uplift and erosion of the Vanzone backfold. The isotopic readjustment or recrystallisation of the monazites at 33-31 Ma may be explained by the penetrative and synmetamorphic rock deformation and related fluid migration, during the Vanzone backfolding and straightening up of the southern steep belt. This deformation phase was also accompanied by the mantle derived $30 \mathrm{Ma}$ porphyritic andesite and 29-25 Ma crustal aplite and pegmatite intrusions (Fig. 16a; Romer et al. 1996; Schärer et al. 1996). The mesoalpine Barrovian regional metamorphism of the Central Alps resulted from complex thermal perturbations in the crust, related to continental collision, nappe stacking, folding, doming (Lepontine dome, Vanzone backfold) and heat advection by extruding nappes and synorogenic mantle derived plutons and dykes (Bergell and Biella granodiorites and tonalities and porphyritic andesites; (Beccaluva et al. 1983; von Blanckenburg 1992; Trommsdorff \& Nievergelt 1983); crust-derived acidic dykes (aplites and pegmatites) and metamorphic fluids (Romer et al. 1996; Schärer et al. 1996).

\section{N-NW-directed fold nappes and thrusts}

The late Alpine uplift and erosion of the Lepontine gneiss dome offer the opportunity to study, in the Central Alps, a complete transect from the cold tectonic lid of the orogen to the complex structures of the deep tectonic level of the Alpine nappe stack, deformed under upper amphibolite facies conditions. The nappe stack represented on Plate 1, Fig. 1 and Tables 1 and 2 is similar to that illustrated on the geological and tectonic maps of Switzerland 1:500'000 (2005) and the 1:100'000 tectonic maps of the Alps of western Switzerland (Steck et al. 1999; 2001) and of the Sopra Ceneri (Berger \& Mercolli 2006). Fig. 5 illustrates the classical geological profile of the Simplon railway tunnel after Schardt (1903), Schmidt \& Preiswerk (1905), Milnes (1973), Steck $(1984,1987)$ updatet with results from the Val d'Anniviers and Visp-Zermatt valley seismic profiles (Marchant et al. 1993, Steck et al. 1997, Steck in Delaloye et al. 2005). Most of the basement nappes of the Helvetic and lower and middle Penninic domains have a fold-nappe geometry, with a well developed inverted fold limb (Fig. 5-9); Argand 1911, 1916; Steck 1984, 1987; Epard 1986; 1990; Escher et al. 1993; Genier et al. 2008). The basement folds, fold nappes and the sedimentary cover nappes are characterized by an initial $\mathrm{S}$ to SE-plunging stretching lineation XI (XI = stretching lineation of deformation phase DI, further explanation see below) and mainly top-to-the N and NW directed shear indicators (Figs. 6 \& 7a; Masson et al. 1980; Steck 1980, 1984, 1987, 1990; Sartory 1987; Steck \& Hunziker 1994; Genier et al. 2008).

The understanding of the present paper needs a short discussion of the used definitions and nomenclature of deformational structures. Folds, schistosities and shear zones are distinguished. Arabic numbers (S1, S2, S3 ... and F1, F2, F3 ...) designate schistosities or crenulation cleavages and folding phases. Roman numbers (XI, XII, XIII \& XIV) designate the specific stretching lineation of ductile shear zones and of deformation phases DI-DIV. $X$ denote the great axes of the strain ellipsoid on the schistosity plain defined by the $\mathrm{Y}$ and $\mathrm{Z}$ axes (Ramsay 1967). These structures may be considered as deformation phases, that last for a certain time and are syn- or heterochronously in space. A specific deformation may also develop at different places either syn- or heterochronously. This may be illustrated by the following examples. In the Doldenhorn foldnappe and also in the Simplon area the same stretching lineation XI was observed associated to a succession of schistosities and crenulation cleavages S1-S2 or S1-S3, testifying of a mechanism of progressive rotational deformation in a same shear zone. In the Doldenhorn foldnappe three schistosities and folding phases S1-S3 and F1-F3 were developed in its mylonitic inverted limb and only one or two schistosities and folding phases occurred in its less deformed normal limb and fold hinge (Steck 1984).

The nappe emplacement took place in a regime of ductile deformation by extrusional flow. Epard \& Escher (1996) and Escher \& Beaumont (1997) suggest a mechanism of simple shear flow and superimposed wedge-shaped pure shear flow. ${ }^{40} \mathrm{Ar} /{ }^{39} \mathrm{Ar}$ white mica ages in the Middle Penninic Siviez-Mischabel nappe, characterized by the XI-stretching lineation, are 40-35 Ma (Fig. 6; Markley et al. 1998). This is the age of the Barrovian metamorphism and corresponds to the age of the middle Penninic fold nappe emplacement in the Central Alps, which post-date deposition of the black Eocene flysch of the 


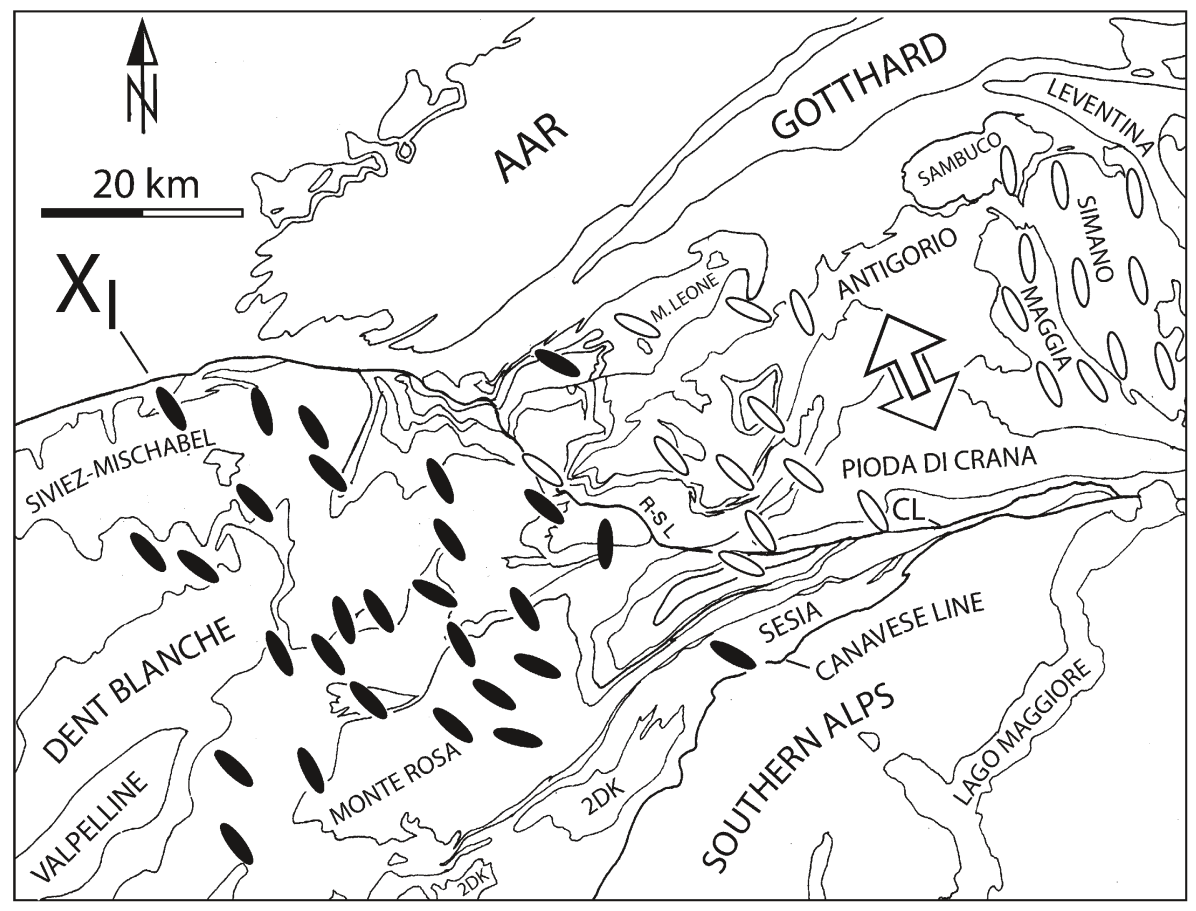

Fig. 6. Orientation of the SE-plunging $\mathrm{X}_{\mathrm{I}}$-stretching lineation (black ellipses) of the Eocene to Earliest Oligocene middle and upper Penninic and Austroalpine nappes, formed between $~ 50$ and $34 \mathrm{Ma}$ and XI-stretching lineation (open ellipses) in Lower Penninic nappes, formed between 34 and $32 \mathrm{Ma}$ (modified after Steck 1990; 2DK = Seconda zona diorito-kinzigitica).
Barrhorn sedimentary cover of the Siviez-Mischabel nappe (Sartori 1987). The thrusting of the Lower Penninic Verampio Monte Leone nappes is younger than the youngest Priabonian flysch deposits of the Valais basin (Fig. 7a, Sion-Courmayeur zone; Bagnoud et al. 1998). The Helvetic thrusts started after the deposition of the Taveyanne flysch, with its 33-32 Ma andesitic volcanites (Ruffini et al. 1995, 1997). The Prealps were thrusted on the sub-Alpine Molasse after 25-23 Ma. The progressive migration of the deformation from internal higher to external deeper nappes is well documented by the structural relations between the Lebendun nappe with its three schistosities and the younger Antigorio nappe with its two schistosities, that correspond to the second and third schistosities of the older Lebendun nappe (Fig. 5, 7a).

\section{W, SW and S-verging transverse folds}

The fan shaped, N- to NW-directed thrusting and related stretching lineation XI of the nappe stack was in a late stage overprinted by W-, SW- and S-verging folds. These transversefolds are from $\mathrm{E}$ to $\mathrm{W}$ the Verzasca anticline, the Maggia syncline, the Ziccher anticline and the Wandfluhhorn (Wa) antiformal syncline (Plate 1, Fig. 7b; Steck \& Hunziker 1994; Steck 1998). The steep Maggia syncline was since a long time recognized by Preiswerk (1918), Wenk (1955) and Merle et al. (1992). Merle et al. (1992) suggested that the Wandfluhhorn and Maggia folds were formed under retrograde greenschist-facies conditions. New data, however, show that these transverse folds were still formed under amphibolite facies conditions with fold axes oriented parallel to the XI-stretching lineation (LIV on
Fig. 7b; Wenk 1955; Wenk \& Keller 1969; Steck 1998; Allaz et al. 2005). The Sambuco unit and the steep Maggia transverse fold are represented on the tectonic map and the block diagram (Plate 1, Fig. 1) as two klippen situated above the Antigorio and Simano nappes, following the observations of Keller et al. (1980) on the geological map sheet "Campo Tencia". The limit between the Biotite-hornblende-plagioclase-Alpigia-tonalitegneiss of the Antigorio nappe and the Simano metapelite may be an intrusive contact in a single Antigorio-Simano nappe and not a tectonic limit of two nappes. An other solution, also based on the observations of Keller et al. (1980), was proposed by Berger \& Mercolli (2006). For these autors the Sambuco unit represents a sub-unit of the Simano nappe. The models of Grujic \& Mancktelow (1996) and Maxelon \& Mancktelow (2005), which consider the Maggia steep zone as a nappe sheet that separates the deeper Antigorio from the higher Simano nappe, are incompatible with the field data and geological map of Keller et al. (1980; Steck 1998; Kröner 2000; Berger \& Mercolli 2006; Plate 1). The Maggia and Sambuco units are represented on the map of Keller et al. (1980) as two synclines (klippen) on top of the Antigorio - Simano nappes. The major difference between the interpretation of this study in agreement with Keller et al. (1980) and the models Grujic \& Mancktelow and Maxelon \& Mancktelow, respectively is, that the latter interpret the Mogno fold (Mesozoic sediments that separates the Maggia from the Simano nappe) at Fusio as a simple syncline, while in this study the Mogno fold is interpreted as a antiformal syncline. The axis of this antiformal syncline plunges with an angle of $20^{\circ}$ to the $\mathrm{S}$, and consequently it represents an antiform and the Maggia nappe is situated above both the An- 
tigorio and Simano nappes (Preiswerk 1919; Preiswerk et al. 1934; Steck, 1998). A similar geometric relation is observed to the $\mathrm{S}$, where the Maggia nappe overlies the Someo-Cimalunga and the deeper Antigorio-Simano nappes (Plate 1, Fig. 1; Steck 1998; Burri 2005; Berger et al. 2007; Brower et al. 2005). The amplitude of the transverse folds grows drastically from $\mathrm{N}$ to $\mathrm{S}$ and with depth, with the increasing, temperature-dependent ductility of the deformed gneisses. The frontal NE-striking anticlinal F2-fold hinge, of the Antigorio - Simano nappes, is only folded by the Maggia transverse fold. The amplitude of the Maggia syncline decreases and disappears in the frontal Sambuco spoon and it increases in the Maggia nappe to the $\mathrm{S}$. The isoclinal Ziccher anticline and Wandfluhorn antiformal synclines do not fold the frontal Antigorio hinge. Their amplitudes increase drastically from $\mathrm{N}$ to $\mathrm{S}$ and with depth, where they reach amplitude of over $25 \mathrm{~km}$. This change in style of deformation with depth, observed in the Lepontine gneiss dome, is interpreted to illustrate the progressive passage from a more rigid high tectonic level in the $\mathrm{N}$, to a very ductile deep tectonic level of the Alpine nappe stack in the S. It is possible that the S-SW-verging Mischabel (10 on Figs. 8-11), Stockhorn and Cimalegna folds ( 2 on Figs. 8-11), that are situated in a higher (greenschist facies) tectonic level of the orogen, belong to the same phase of deformation (D4, F4, Plate 1, Figs. 8, 9, 11). The huge SW-verging nearly isoclinal transverse folds of the Lepontine gneiss dome suggest a NE-SW shortening, perpendicular to the foldaxis and a W-directed drift of the Adriatic front simultaneously with its NW-W-directed over thrusting. The formation of the SW-verging transverse-folds may be considered as a phase of transition between the early nappe detachment during the SE-directed underthrusting of the European plate below the Adriatic plate and subsequent movements of dextral transpression in the zone of continental collision in the dextral Simplon ductile shear zone. More details are given in the next chapter. Note, that the described model for the Wandfluhhorn transverse fold differs fundamentally from the dissimilar models proposed by Milnes (1974) and Maxelon \& Mancktelow (2005). The axial surface of the Wandfluhhorn fold is identical with the axial surface of the Monte Leone fold nappe in the Milnes (1974) model. The axial surface of the Wandfluhhorn fold is identical with the axial surface of the frontal Antigorio fold nappe in the Maxelon \& Mancktelow (2005) model. The Wandfluhorn fold deforms the normal limb of the Antigorio F2 fold (Plate 1). That means that this fold belongs to a younger deformation phase and for this reason the axial trace of the Antigorio recumbent $\mathrm{F} 2$ fold cannot be identical with the axial trace of the Wandfluhhorn F4 fold, as proposed by Maxelon \& Macktelow (2005). The Monte Leone nappe is folded together with the Bosco-Isorno-Orselina, Bombogno (= Lebendun) and the normal limb of the Antigorio F2-fold in the Wandfluhhorn F4-fold (Plate 1). Milnes (1974) supposed that the axial trace of the Wandfluhornfold continues farther ouest as axial trace of a isoclinal Monte Leone foldnappe. This suggestion is unlikely, because the frontal Monte Leone nappe fold hinge near Visp is a second F2-fold like the frontal Antigorio F2-fold, that is refolded by the younger Wandfluhhorn fold. The geometrical information's represented on the structural map (Plate 1 and the 1:100'000 tectonic map of the Alpes of western Switzerland by Steck et al. 1999) show clearly that the Wandfluhhorn F4fold deform both, the pre-existing NW-verging Antigorio and Monte Leone F2-fold nappes (Steck 1987; Steck \& Hunziker 1994).

\section{The dextral Simplon ductile shear zone}

A second SW-oriented stretching lineation, XII, is related to NE-SW extension and top-to-the SW shear of the Simplon ductile shear zone (Fig. 7c; Steck 1980, 1984, 1990; Dolivo 1982). The northern and southern boundaries of this 10-20 km thick, (on the map up to $30 \mathrm{~km}$ wide), $\sim 25^{\circ}$ south dipping, dextral shear zone, cross the Alps obliquely in a W-E direction, from the Helvetic zone to the $\mathrm{W}$ to the Austroalpine Sesia zone to the E. The formation of open folds F5 with axis and dextral shear parallel to the stretching lineation are probably contemporaneous, as discussed later. The second deformation DII (XII) transposes an earlier schistosity with the older XI-stretching lineation (DI), often without forming a new schistosity. The final deformation corresponds in this case to the sum of the two deformation phases and the sense of shear indicators are difficult to interpret. A minimum SW-directed displacement, of the hanging-wall of the Simplon shear zone of about $60 \mathrm{~km}$ was estimated, based on a quantification of the finite strain ellipsoid and the width of the shear zone (Steck 1984). Xenoliths in granite gneisses and pebbles in conglomerates as well as the total width of the ductile Simplon shear zone were used for quantification. A minimal relative displacement of $60 \mathrm{~km}$ was calculated for a mean value of $1+\mathrm{e} 1=4$ parallel to the stretching lineation XII and a mean thickness of $15 \mathrm{~km}$ of the Simplon ductile shear zone. The deformation of the very ductile calcschists, separating the gneiss folds, was certainly more intense, so that the displacement was probably in the order of $100 \mathrm{~km}$. That means that also the Sesia-Dent Blanche nappe and the Southern Alps have been displaced by 60 to over $100 \mathrm{~km}$ in a WSW-direction relative to the deep-seated European, Verampio, Gotthard and Aar units (Steck 1980, 1984, 1990).

31-29 Ma porphyritic dikes crosscut stretched gneisses in the Loana valley, with a pre-existing intense amphibolite facies stretching lineation XII. The dikes are then overprinted by a weaker younger mineral stretching XIV parallel to XII (Fig. 17). Similar age relations are observed with the 29-25 Ma aplites and pegmatites of the Vigezzo valley steep zone, between the Toce valley and Locarno (Fig. 16a). The third Deformation DIII with a steep NW-plunging Stretching lineation XIII, and with top-SE sense of shear was not observed in the steep belt between Domodossola and Locarno. The Stretching lineation XIII was developed in the mylonites of the Sesia zone (schisti di Fobella et Rimella) along the Canavese line from the Toce valley to the SE (Steck 1990). The formation of the dextral Simplon ductile shear zone started before $30 \mathrm{Ma}$, probably around $32 \mathrm{Ma}$ ago, and continued until $18 \mathrm{Ma}$, the time when it was 
a)

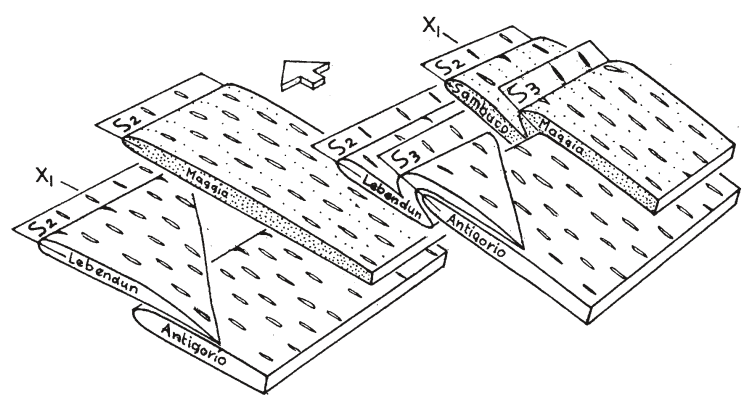

NW-directed Lower Penninic thrusts $\left(\mathrm{X}_{\mathrm{I}}\right)$ : 34-32 Ma

c)

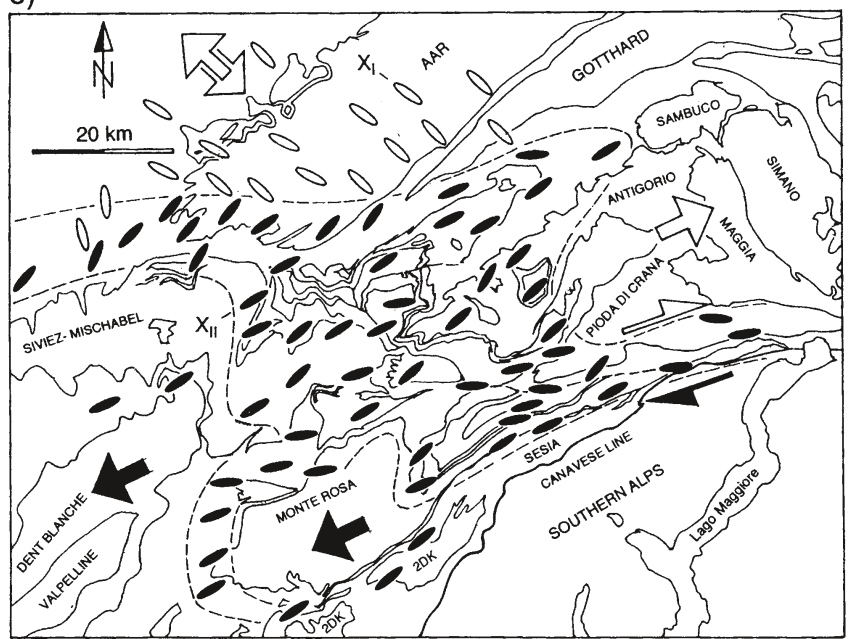

NW-directed Helvetic thrusts $\left(X_{1}\right): \sim 32-16 \mathrm{Ma}$

SW-directed Simplon ductile shear zone $\left(\mathrm{X}_{||}\right): \sim 32-18 \mathrm{Ma}$

SE-verging Vanzone backfold: 30-18Ma b)

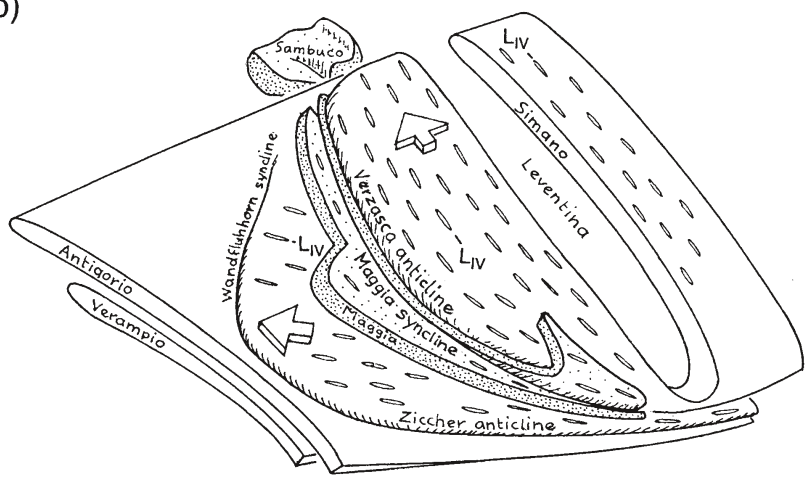

W - S-verging transversefolds $\left(\mathrm{L}_{\mathrm{IV}}=\right.$ transposed $\left.\mathrm{X}_{\mathrm{I}}\right)$ : $\sim 32 \mathrm{Ma}$

d)

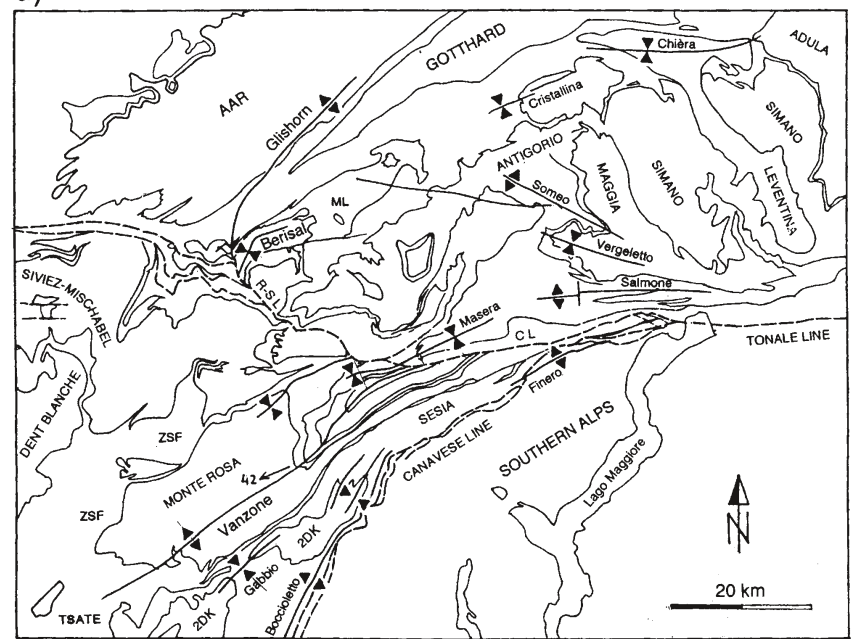

Rhone-Simplon line: 18-15, 11-10, 5-0 Ma

Centovalli line: 14-4 Ma, Maserasyncline

Glishorn - Berisal backfolds: 10 Ma

Fig. 7. a-d) The four main phases of structural evolution (a-d) of the Simplon area during continental collision of Europe and Adria (modified after Steck 1990): a) The NW-directed, 34-32 Ma lower Penninic thrusts and folds, with a SE-plunging stretching lineation XI. b) The $\sim 32$ Ma W-S-verging transverse folds ("Querfalten"), Verzasca anticline, Maggia - Sambuco syncline, Ziccher anticline and Wandfluhorn syncline (the Cimalunga-Someo unit, see Plate 1, is not represented). c) The 32-18 Ma, 10-15 km thick dextral Simplon ductile shear zone, with its SW-dipping stretching lineation XII (black ellipses), crosses the Central Alps from the Helvetic zone to the W to the Austroalpine Sesia zone to the E. This dextral shear occurred contemporaneously with the 32-16 Ma NW-directed Helvetic thrusting, parallel to the XI-stretching lineation (open ellipses). Formation of SE-verging Vanzone backfolds since $30 \mathrm{Ma}$ and during dextral strike-slip movements on the Simplon ductile shear zone. d) Formation of the more discrete dextral Rhone-Simplon line (R-SL) since $18 \mathrm{Ma}$, the 10 Ma Glishorn - Berisal backfold and before and during this time, the 14-4 Ma detachment and dextral strike-slip movements on the Centovalli line (CL).

relieved by the discrete (more brittle) dextral Rhone - Simplon line (Steck, 1984; Steck \& Hunziker 1994; Romer et al. 1996; Schärer et al. 1996). The DII dextral shear deformation is dated by ${ }^{40} \mathrm{Ar}{ }^{39} \mathrm{Ar}$-ages on synkinematic white mica in the range of 35-30 Ma in the Visp valley (data of Markley et al. 1998). Markley et al. (1998) interpreted these ages as the result of thermic rejuvenation above the $18-15 \mathrm{Ma}$ Simplon normal fault. In this study the data of Markley et al. (1998) are interpreted as the age of the synmetamorphic deformation in the ductile Simplon shear zone (Genier et al. 2008). The Helvetic nappes and the frontal Aar massif basement folds were thrusted between 32 and $16 \mathrm{Ma}$ parallel to the XI-stretching lineation to the NW and this during the dextral transpression in the Simplon ductile shear zone (Fig. 7c; Steck 1984, 1990; Lacassin 1989).

\section{S-SE verging back folds (Vanzone and Bergell back folds)}

The Simplon ductile shear zone is folded by the SE-verging Vanzone back fold and this during activity of dextral ductile shear (Figs. 7c, d \& 8-12). Argand $(1911,1916)$ named this phase of Alpine back folding the Insubric phase. The folding of the schistosity, with the SW-directed stretching lineation, XII, can be studied in good outcrops in the Antrona valley. The stretching lineation XII is parallel to the fold axis in the Van- 


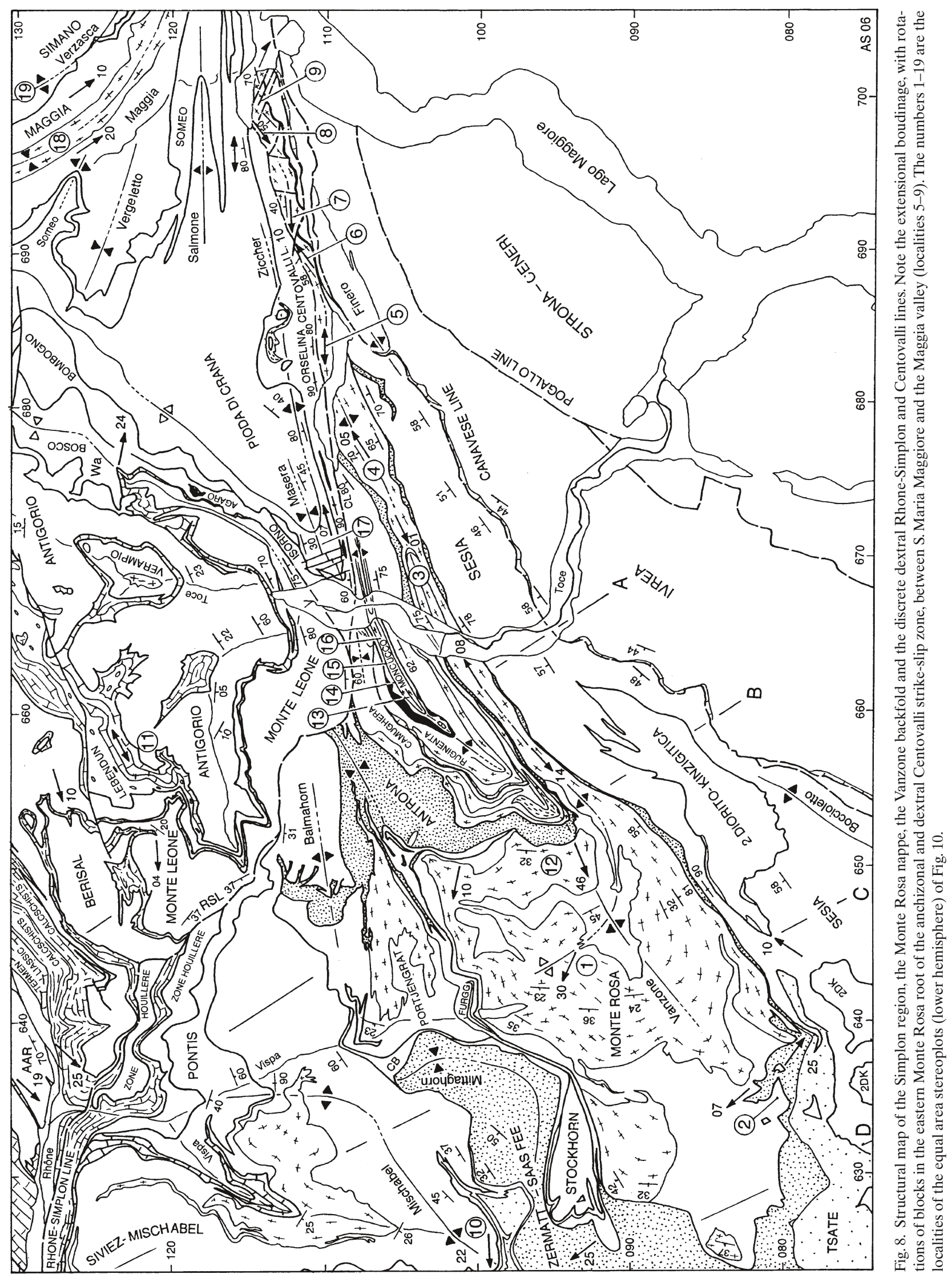




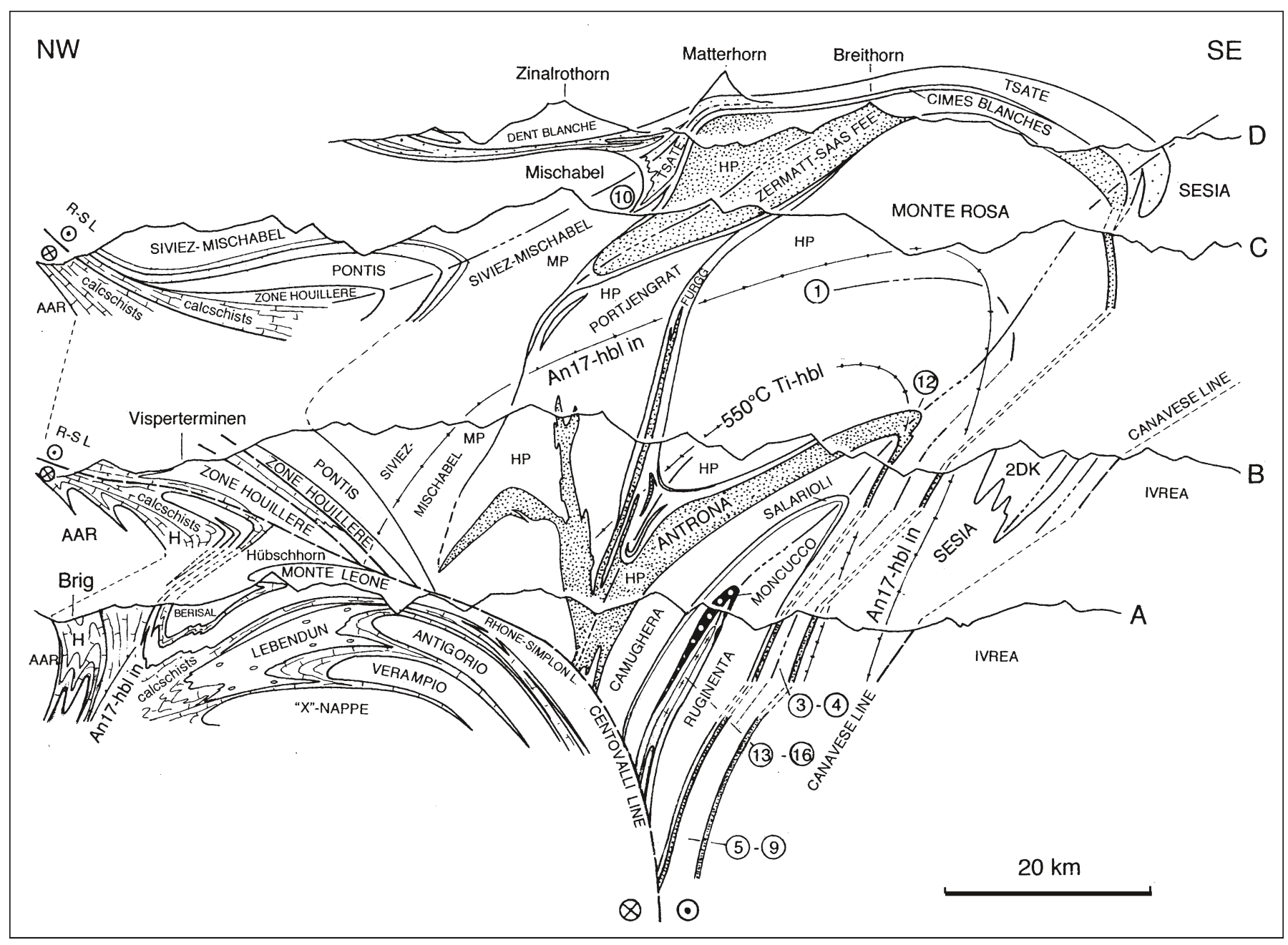

Fig. 9. NW-SE oriented geological sections through the Simplon region (Sections A, B, C and D on Fig. 7; MP = Barrovian Medium pressure metamorphism, HP = High to Ultra-High Pressure metamorphism; $550{ }^{\circ} \mathrm{C}$ isotherm of the Ti-hbl geothermometer, after Colombi 1989).

zone fold (equal area nets 12-16 on Fig. 11). The XII-lineation is in rare cases itself folded, whereas in other cases, younger fold-axis-parallel dextral shear overprints the two limbs of the Vanzone anticline (Fig. 14). These observations lead to the conclusion that the dextral shear preceded, accompanied and outlasted the back folding (Steck 1990; Keller et al. 2005). The geometry of the hinge of the Vanzone backfold changes gradually from $\mathrm{W}$ to $\mathrm{E}$, with the increasing grade of the Barrovian regional metamorphism, from greenschist grade on the western border of the Monte Rosa nappe to amphibolite facies grade with staurolite and kyanite, in the Toce valley. Also the fold geometry changes, with the increasing ductile deformation from an open fold at the western border of the Monte Rosa nappe (locality 2 on Fig. 8-11), to an isoclinal, as seen in the granitic gneiss of the Moncucco unit in the core of the Vanzone fold (Milnes et al.1981, see also Steck et al.1979; Plate 1, Figs. 8-12). The observations on the geometry and the axial surface trace of the Vanzone fold of this study (Plate 1, Figs. 2, 8-12) differ from the geological map and description published by Keller et al. (2005, Fig. 3; Keller et al. 2006). After Keller et al. $(2005,2006)$ the Vanzone axial trace does not continue into the Moncucco granite gneiss; it ends to the $\mathrm{N}$ of the Moncucco peridotite and the Moncucco summit. These authors interpret its continuation farther NE by en-echelon anticlines and synclines such as their Brevettola antiform and Masera synform. In our interpretation the latter are secondary folds formed during retrograde metamorphic conditions in the northern limb of the main Vanzone anticline. While this study distinguish the amphibolite facies Vancone fold (old, Fig. 12, 13a \& b) from the greenschist facies and anchizonal low grade structures of the Masera fold system (Fig. 15). Keller et al. $(2005,2006)$ interpret a contemporaneous evolution of the folds.

The fold hinge of the Vanzone fold is well exposed at the type locality, north of the village of Vanzone, where the Antrona ophiolites are folded together with Monte Rosa and Camughera gneisses (Bearth 1956b, 1957). We followed from 
there the axial trace to the E. The fold hinge is exposed at the Salarioli pass, at the southern head of the bridge of Ruginenta in the Antrona valley (Fig. 3,14), at Alpe Pradurino (where the hinge is marked by an outcrop of white siliceous marbles, surrounded on both fold limbs by meta-pelites and the Moncucco peridotites, Bearth 1956b), and at the southern ridge of the Moncucco (situated in the core of the porphyritic Moncucco granite gneiss; Fig. 12 \& 13a,b). The trace of the Vanzone fold continues farther $\mathrm{E}$ in the core of the Moncucco granite gneiss. It is crossed in two places by the Domodossola - Alpe Lusentino road and reaches the Toce valley below the church of the Calvario of Domodossola. The fold hinge is formed by a paragneiss in the core of the Monucco granite gneiss, exposed in the steep wall behind the Trattoria Isola, on the Beura road on the eastern side of the Toce valley. A last outcrop of the Vanzone fold hinge was observed $3 \mathrm{~km}$ farther $\mathrm{E}$, near the chapel of S. Rocco, at an altitude of $880 \mathrm{~m}$, on the upper end of the road starting at the village of Verigo in the Vigezzo valley (Fig. 3).

The study of the fold hinges in the Moncucco granite-gneiss reveals a postkinematic amphibolite-facies growth texture of quartz, K-feldspar, plagioclase, with myrmekite (plagioclase + quartz) overgrowth of K-feldspar, muscovite and biotite (Figs. 12, 13a, b). The Vanzone structure folds the isopleths of the Ti-content in hornblende and the isograd marked by the reaction: albite $=$ edenite +4 quartz, of the Barrovian regional metamorphism. The hinges of the folded isograds are situated farther $\mathrm{N}$ of the Vanzone fold hinge, as outlined by the lithologic boundaries (Fig. 9, 10; Colombi 1989). This discordance between folded isograds and lithological boundaries may suggest that the cooling by exhumation and folding controlled erosion was synmetamorphic and that the cooling was greater in the southern fold limb, in contact with the colder Ivrea rocks south of the Canavese line, than in the Alpine metamorphic gneiss dome to the N. An additional argument for synmetamorphic high temperature folding of the Vanzone anticline is the postkinematic amphibolite facies fabric in the fold hinge of the Moncucco granite gneiss (Figs 12 \& 13a, b). The LA PMMS U$\mathrm{Pb}$ Monazite ages vary between 33 and $26 \mathrm{Ma}$ in Monte Rosa gneiss samples from Beura, the Pizzo Tignolino and the Pizzo Ragno (Engi et al. 2001). These young monazite ages may be explained by rejuvenation or crystallisation related to a penetrative deformation and simultaneous fluid migration in the synmetamorphic Vanzone back fold. This may also be the starting age of the synmetamorphic uplift and cooling of the Vanzone back fold north of the Canavese line. The Insubric phase of back-folding was responsible for the rapid cooling, by uplift and erosion of the Central Alpine root zone and the creation of the southern steep belt between the Ossola valley and the Bergell area, since 30 Ma (Hurford 1986; Schmid et al. 1987; Hunziker et al. 1992; Steck \& Hunziker 1994; Berger at al. 1996; Schmid et al. 1996). Zircon and apatite fission track data from the Toce valley suggest, that vertical displacements related to the Vanzone back-folding ended between 12-6 Ma ago (Fazis 2004; Keller et al. 2005). These authors observe no jump in the zircon and apatite fission track ages along the Verampio-
Piedimulera transect of the Toce valley. The fission track ages range between 6.4-12 Ma for zircon and 2.2-5.8 Ma for apatite and become progressively older going from north to south, indicating a late regional uplift of the more northern parts of the area around the Toce culmination. However, these data do not exclude the continuation of horizontal strike-slip displacements along the Simplon - Centovalli lines.

\section{The Oligocene intrusives of the southern steep belt}

The intrusives of the southern Alpine steep belt, between the Toce valley and Locarno, are of two types:

1. mantle derived tonalites and granodiorites (Biella, Traversella, Bergell) and porphyritic andesites

2. aplites and pegmatites, derived from melts of crustal anatexis, exposed in the steep zone between Domodossola to the $\mathrm{W}$ and the Bergell intrusion to the E (Fig. 16a).

The first group (1), the so-called periadriatic intrusions, were formed from basaltic magmas by partial fusion of the mantle lithosphere and mixed with anatectic crustal magmas (Trommsdorff \& Nievergelt 1983; Berger et al. 1996). They are dated 32-29 Ma (Beccaluva et al. 1983; von Blanckenburg 1992). Von Blanckenburg et al. (1998) suggest that this 30 Ma magmatic event was related to a slab break-off of the root of the European lithosphere. The second group (2) consists of aplites and pegmatites, dated between 29-25 Ma (Romer et al. 1996; Schärer et al. 1996) and derived from the partial melting of upper crustal rocks, at a deeper migmatic level of the Tertiary Barrovian regional metamorphism within the southern steep zone. Contact of the dikes with the surrounding migmatites of the Palaeozoic basement gneisses is always sharp (Fig. 16a). Two samples of the Hercynian migmatite leucosomes from Corcapolo (Fig. 16a) and Lavertezzo reveals ages of 280-290 Ma (Romer et al. 1996). Migmatites of undisputed Oligocene age are only observed between Bellinzona and the Bergell (Hänni et al.1975). Oligocene dikes were used to date the deformation in the southern steep belt (Zingg \& Hunziker 1990; Steck \& Hunziker 1994; Romer et al. 1996; Schärer et al. 1996). These porphyritic dikes, aplites and pegmatites are younger than the E-W-striking amphibolite facies grade XII-stretching lineation (Fig. 16a). Only slightly deformed crosscutting dikes are frequent in the steep dipping gneisses between the Toce valley and Malesco. Between Malesco and Locarno, the aplites and pegmatites are in many places sheared and folded by low-temperature (anchizone) deformation, related to the late Alpine movement at the Centovalli fault zone. The main amphibolite facies schistosity, with its relicts of a steep XI and the main subhorizontal XII-stretching lineation, are often overprinted by a younger low-grade schistose deformation, with a subhorizontal stretching lineation XIV associated with dextral shear indicators (Fig. 17). These young structures are depicted, together with the pre-existing dominant amphibolite facies schistosity and XII-stretching lineation on the stereonets 6-9 on Fig. 11. The stereo plots of Fig. 17 illustrate the similar orientation of 


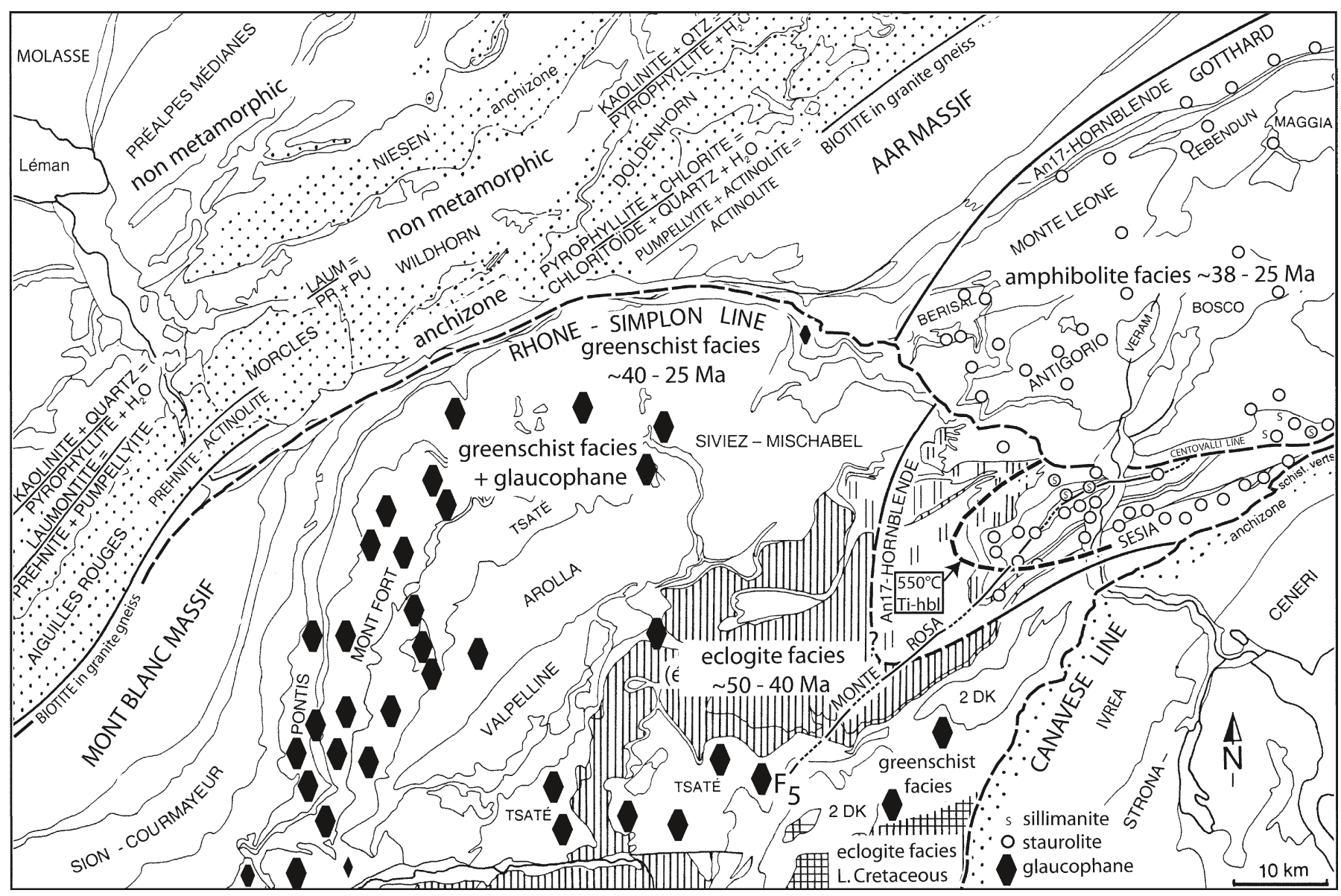

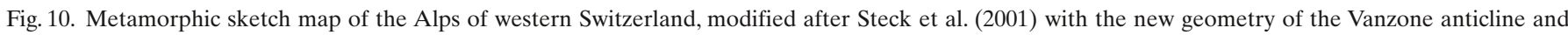

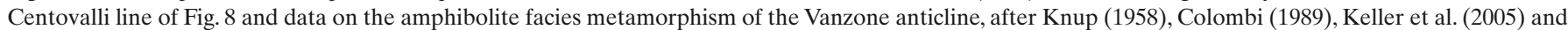

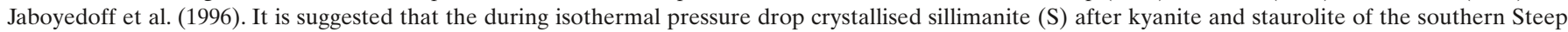
belt (Knup 1958; Keller et al. 2005) was formed during the Vanzone fold uplift and erosion.

the old amphibolite facies XII and younger anchizonal XIV stretching lineations, observed on the Palagnedra - Moneto road.

\section{The dextral Rhone-Simplon line, the related Lepontine dome and Valpelline pull-apart depression.}

The deformations in the Simplon ductile shear zone are followed by movements on the schistosity-parallel, younger and more discrete dextral and low-angle normal fault of the RhoneSimplon line (Plate 1, Figs. 1, 7d \& 8; Steck 1980, 1984, 1990; Mancktelow 1985, 1990; Grosjean et al. 2004). It is the Simplon line at the Simplon pass discovered and described by Bearth (1956a) as a normal fault, that limits the amphibolite-facies metamorphic rocks in the $\mathrm{E}$ from greenschist-facies rocks to the W of the fault (Fig. 10). Steck (1984, Steck et al. 1999, 2001) followed the fault zone further W over the Nanzlücke, Gebidum and Visperterminen to the Rhone valley and at Martigny to the Chamonix zone and named it Rhone-Simplon line. In the Rhone valley, between Turtig, Niedergestelen and Martigny,
Quaternary alluvial deposits hide the main fault. But the line is marked on both sides of the Rhone valley by numerous, valleyparallel, dextral strike-slip faults. The main branch continues in the Chamonix zone to the $\mathrm{S}$ of Martigny, between the Mont Blanc and Aiguilles Rouges massifs (Gourlay \& Ricou 1983; Gourlay 1984; Steck 1984,1990; Epard 1986; 1990; Hubbard \& Mancktelow 1987; 1992; Steck et al., 1999, 2001). To the east the $3 \mathrm{~km}$ wide Toce alluvial plain covers the eastern continuation of the Simplon line. Mancktelow (1985) suggest its continuation in the Isorno valley, following the southern boundary of the Monte Leone gneiss whereas Bearth (1956a) propose that the Simplon line is also related to the Centovalli line. Keller et al. (2006) conclude that the Simplon line finishes in the lower Bognanco valley where the Camughera gneiss continues in the Monte Leone gneiss. New field work (structural map on Plate 1, Fig. 3, 8-11) reveal that its eastern continuation corresponds to the Centovalli line also a main dextral strike-slip fault. It cuts discordantly the Moncucco, Ruginenta, Camughera, Antrona and Monte Rosa units between the Toce valley and S. Maria Maggiore in the Viggezzo valley and continues farther E up 


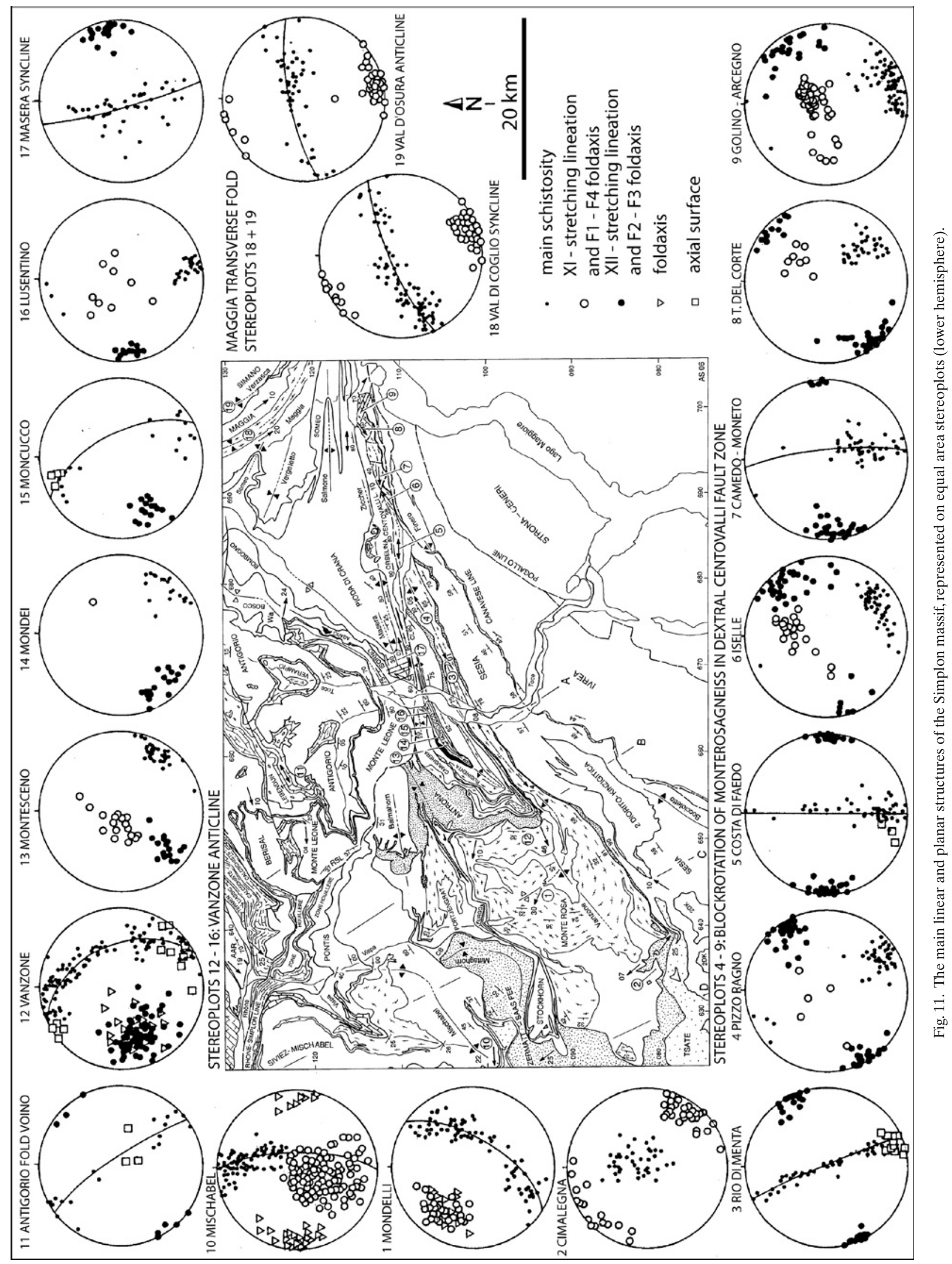




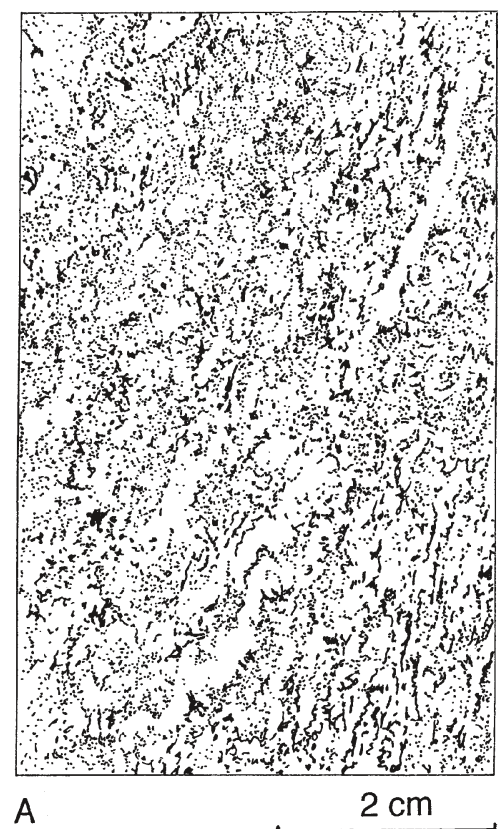

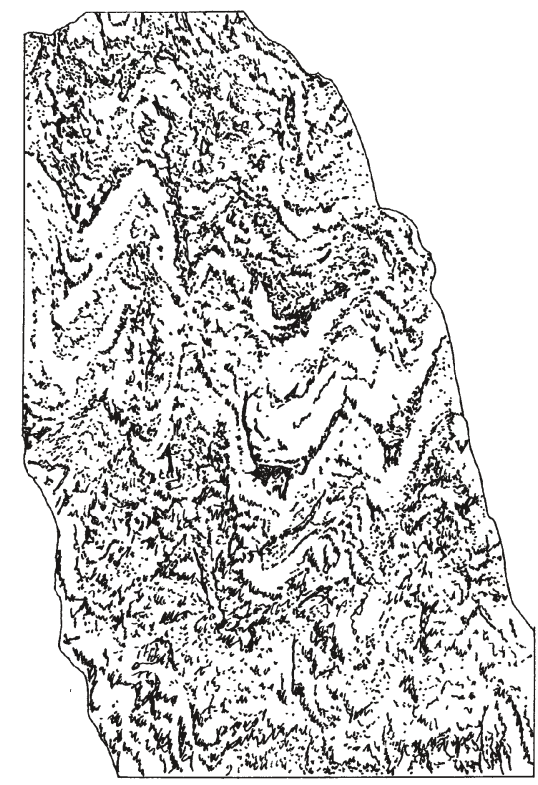

B AS0527

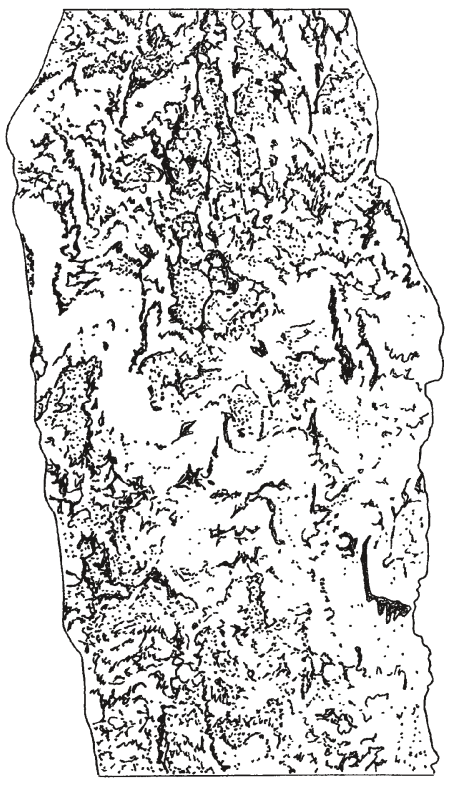

C

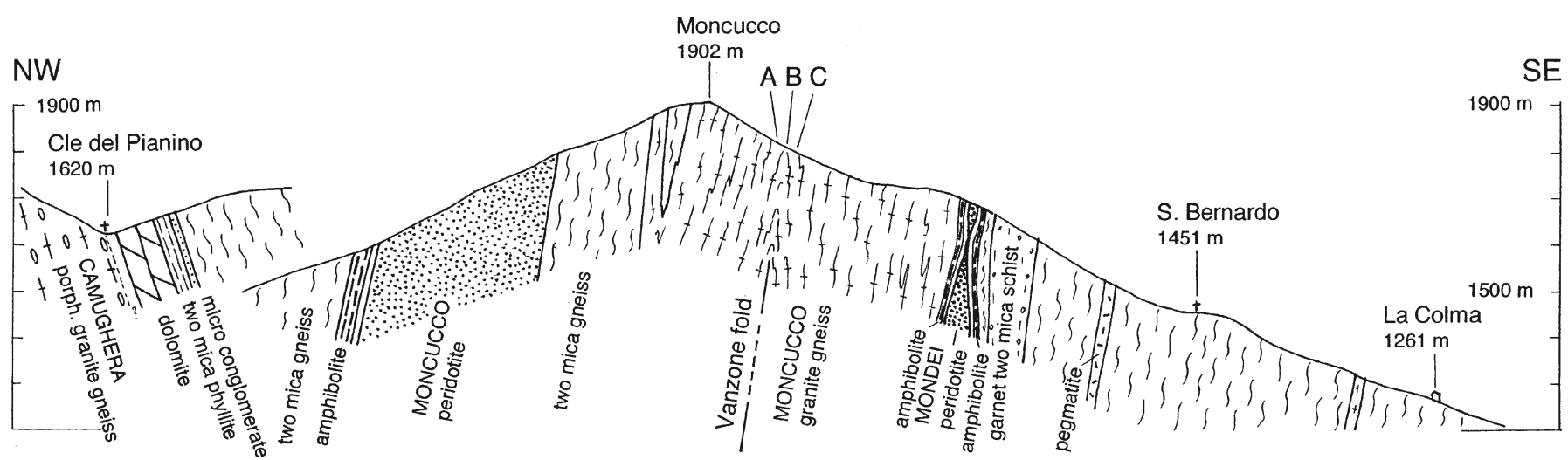

Fig. 12. NW-SE geological section and fold structures of the hinge zone of the Vanzone anticline in the Moncucco muscovite-biotite granitegneiss, exposed at an altitude of $1800 \mathrm{~m}$ in the southern ridge of the Moncucco.

to Intragna (Fig. 3) at the northern border of the Monte Rosa gneiss (for more details see next section). The displacement on the about $30^{\circ} \mathrm{SW}$-dipping normal fault, was estimated of $\sim 14 \mathrm{~km}$ at the Simplon pass (Hunziker 1969; Hunziker \& Bearth 1969; Mancktelow 1985, 1990; Grasemann \& Mancktelow 1993). The activity of the Simplon line was dated in the Simplon pass region with the Rb-Sr method on muscovite and biotite, by Hunziker (1969), Hunziker \& Bearth (1969), and with the zircon and apatite fission-track method by Soom (1990; Hunziker et al. 1992; Steck \& Hunziker 1994). Two periods of very rapid cooling of the footwall of the Simplon line, of $37.5^{\circ} \mathrm{C} / \mathrm{Ma}$, occurred between 18-15 Ma and 11-10 Ma and a third of $45^{\circ} \mathrm{C} / \mathrm{Ma}$ from $5 \mathrm{Ma}$ up to the present. These three periods of rapid cooling are related to tectonic exhumation, unroofing and erosion of the Aar-Toce culmination of the western Lepontine gneiss dome (Hunziker et al. 1992; Grasemann \& Mancktelow 1993; Steck
\& Hunziker 1994). High exhumation rates of $3 \mathrm{~km} / \mathrm{Ma}$ for the Bietschhorn region of the western Aar massif were dated of $6 \pm 0.5 \mathrm{Ma}$ by the zircon U-Th/He thermochronology by Aramowicz et al. (2007). The strong uplift and erosion of the Alps since $5 \mathrm{Ma}$ is also in agreement with the up to $9 \mathrm{~km}$ thick sediment filling of the Po Molasse basin above the base of Pliocene Isobaths (Barberi \& Scandoni 1986). The progressive cooling to temperatures below $300{ }^{\circ} \mathrm{C}$ of the Lepontine gneiss dome, by uplift and erosion, started some $30 \mathrm{Ma}$ ago in the Bergell area to the $\mathrm{E}$ and along the Tonale - Canavese line to the $\mathrm{S}$, and ended some $10 \mathrm{Ma}$ ago in the Simplon-Brig area, as was demonstrated by the $\mathrm{Rb}$-Sr biotite cooling ages published by Hunziker \& Bearth (1969; Steck \& Hunziker 1994). The very low $\delta \mathrm{D}$ and $\delta^{18} \mathrm{O}$ isotopic values of water trapped some $15 \mathrm{Ma}$ ago, at temperatures of $\sim 350^{\circ} \mathrm{C}$, in quartz crystals from Alpine veins of the Lucomagno region suggest that at this time, the 

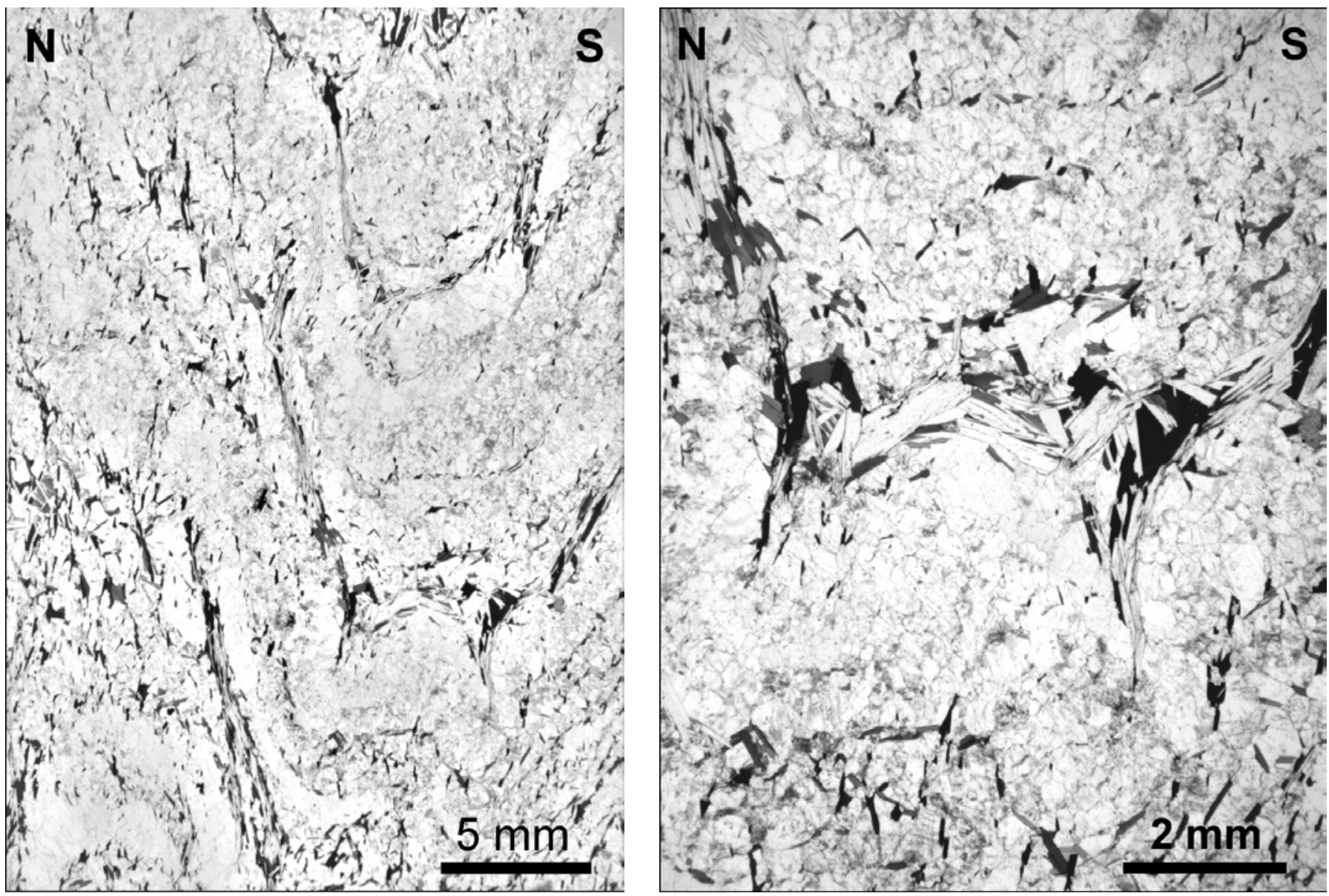

Fig. 13. a, b) Photomicrograph of the Moncucco two-mica granitegneiss, illustrate the postkinematic non-oriented crystallisation of muscovite and biotite, in an amphibolite facies fabric of quartz-K-feldspar-plagioclase-biotite-muscovite, of the Vanzone antiform (sample B, AS0527 on Fig. 12).

summits of the northern Leventina dome were situated at an altitude of up to 5-6000 $\mathrm{m}$ (Sharp et al.2005). The abundance of earthquakes in the vicinity of the Rhone-Simplon line, between Brig and Martigny, and earthquakes focal mechanisms, suggesting dextral strike-slip movements (Maurer et al.1997; Pavoni et al. 1997; Baer et al. 2005), and the high uplift rates of $>1.5 \mathrm{~mm} /$ $\mathrm{yr}$ in the region of Brig (Gubler et al. 1981), testify, that this fault is still active at present. The earthquake focus centres are never situated on the active main fault itself, but on fault parallel planar structures in the neighbouring gneisses, where elastic forces were accumulated and unloaded by fracturing (Kahle et al. 1997; Jaboyedoff et al. 2003).

\section{The Centovalli line}

The Centovalli line is an Alpine fault zone, which follows the Estriking depression of the Vigezzo valley (Melezzo occidentale river) and the Centovalli (Melezzo orientale river), from Trontano, E of Domodossola, to Intragna at the mouth of the Maggia valley. The Maggia alluvial delta and the Lago Maggiore hide its connection with the E-striking Tonale line (Plate 1,
Fig. 1, 3, 8, 11). The western connection of the Centovalli line with the Simplon line is hidden by the over $3 \mathrm{~km}$ wide Toce alluvial plain. It is suggested, that to the $\mathrm{N}$ of Domodossola, the Centovalli line reaches the Simplon line at the entrance of the Bognanco valley (Bearth 1956). Another branch, represented by an up to $10 \mathrm{~m}$ wide cataclastic fault zone (Fig. 16c; fault gouge and in cohesive breccias and cataclasite zone or kakirite zone), follows the bottom of the Bognanco and Loranco valleys further to the W. Combined field and laboratory work reveals a long lasting history of the Centovalli line:

1. The main schistosity of the Vigezzo and Centovalli valleys is characterised by a sub horizontal stretching lineation XII and dextral shear indicators. It was created under amphibolite facies conditions. This schistosity marks the up to $10 \mathrm{~km}$ wide eastern root zone of the dextral Simplon ductile shear zone, that was active since about $32 \mathrm{Ma}$. Relicts of an older, steeply plunging stretching lineation XI, related to the earlier nappe emplacement, are observed in many places.

2. The steep zone was intruded by $30 \mathrm{Ma}$, mantle-derived porphyritic dikes and by 29-25 Ma, crustal aplitic and pegma- 

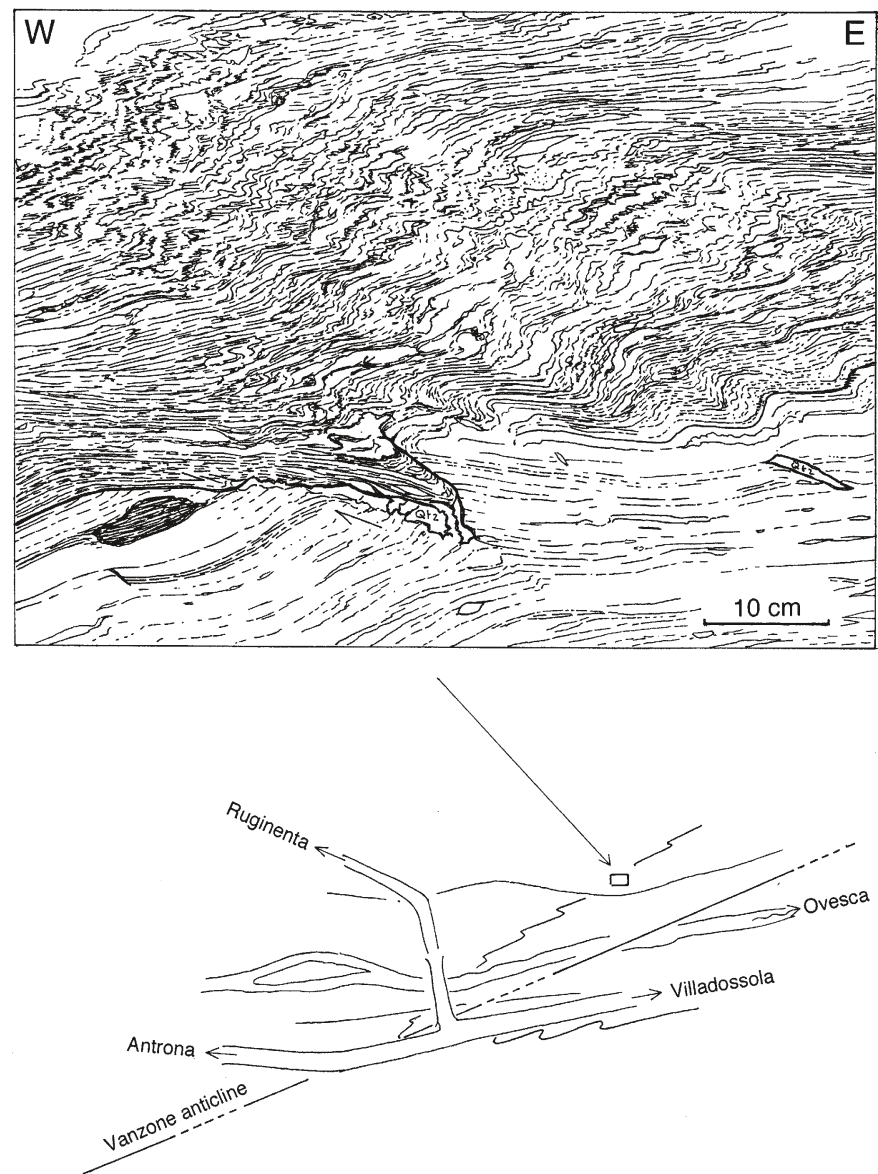

Fig. 14. Late dextral shear structures with quartz veins, that overprint the northern limb of the pre-existing Vanzone fold. Similar structures are common in the Antrona valley.

titic dikes (Romer at al. 1996; Schärer et al. 1996). The dikes cut the main schistosity, with its sub horizontal stretching lineation XII (Fig. 16a). However, the dikes are themselves overprinted by dextral shear zones (Streching XIV on Fig. 17), indicating continued dextral shear during and after intrusion.

3. A more discrete dextral fault was formed during the detachment of the Vanzone back fold $(\mathrm{CL}=$ Centovalli line on Plate 1 and Fig. 1, 3, 7d, 8 \& 9). The structures of the isoclinal Vanzone fold are cut by the E-striking Centovalli line between the Ossola valley and the great alluvial plane of Druogno S. Maria Maggore - Malesco. The Antrona ophiolites form at Gagnone and Druogno, an acute angle of $20^{\circ}$ with the Centovalli line and the ENE-striking banded gneisses of the Bosco - Isorno - Orselina zone to the north (Plate 1; Fig. 3, 8). The main Centovalli fault follows the Melezza river gorge of the Vigezzo valley between Trontano and Gagnone. Cataclastic shear and fault zones, with dextral shear indicators are developed parallel to the ENE-striking Centovalli line and the main foliation of the Orselina zone (Fig. 16b, 17). Conjugate NNWSSE oriented sinistral strike-slip faults crosscut the Masera syncline to the $\mathrm{N}$ of the main Centovalli fault. These conjugate NNW-striking sinistral faults, together with the dominant ENEstriking dextral strike-slip faults, indicate NW-SE compression and SW-NE extension (Wieland 1966; Tischler 2005). The formation of the Masera syncline and of the second-order crenulation and kink folds result from this compression $\mathrm{N}$ of the Centovalli line. The Masera syncline is a late Alpine concentric fold, formed under greenschist-facies conditions (Fig. 15), that overprints the Bosco-Isorno-Orselina gneiss zone (Wieland, 1966) and the pre-existing S-verging Ziccher anticline (Steck et al. 2001). The Centovalli line is covered between Druogno and Malesco by an E-striking and up to a one kilometer wide zone of Quaternary deposits. It is probable that this outcrop-free alluvial plane hides a dextral E-striking fault zone related to the Centovalli fault system. The gneisses of the Monte Rosa nappe are only weakly affected by the Centovalli fault structures to the SW of Druogno-Malesco. The fold axis and the stretching lineation XII have a constant, undisturbed SW-NE orientation (stereographic nets 3 and 4 on Fig. 11; Steck 1984). The Antrona ophiolites disappear and the main cataclastic zone follows the northern ENE-striking border of the Monte Rosa gneiss zone to the $\mathrm{E}$ of the Quaternary valley filling of S. Maria Maggiore and Malesco. Moreover, the main dextral ENE-striking shear zone and the Monte Rosa gneiss zone are cut by younger ESESE-striking dextral and conjugate $\mathrm{N}$-striking sinistral strike-slip faults between Malesco and Locarno, indicating a NW-SE directed compression (1:25'000 geological map sheet 1312, Locarno, Colombi et al. in press). The Monte Rosa gneiss is dismembered in this part of the Centovalli strike-slip zone into kilometre size rotated blocks, in a zone of extensional boudinage and dextral transpression. These block-rotations (Fig. 8) are illustrated by the structures represented on the stereographic nets 4-9 on Fig. 11. The cataclastic deformation of the Monte Rosa granite gneiss is consistent with anchizonal - diagenetic temperature conditions, lower than $200{ }^{\circ} \mathrm{C}$, in the domain of brittle behaviour of quartz. Dextral SE-striking strike-slip faults with an NE-plunging normal-fault component are responsible for the tectonic omission of the Monte Rosa zone, the ZermattSaas-Fee ophiolites, and the Sesia, Canavese and Ivrea zones below the Orselina zone to the E of Locarno (Colombi et al. in press). Similar dextral faults crosscut the Orselina - Bellinzona zone and the Oligocene tonalite intrusion to the $\mathrm{E}$ of Locarno and Bellinzona, in the $\mathrm{N}$ of the dextral and also Late-Alpine Tonale fault (Plate 1). A N-down offset of the late Alpine dextral Tonale fault is responsible for the tectonic omission of the older high-temperature structures of the pre-existing Canavese (Insubric) line at depth.

4. Late normal fault movements on ENE-striking and NNW-dipping faults, in the Finero anticline and along the Canavese line indicate a late phase of vertical compression and NNW-SSE extension, and may be of a regional late Alpine phase of NNW-SSE extension (Steck \& Tièche 1976).

The mineralogy of the cataclastic zones and fault gouges of the Centovalli line was studied by Surace (2004). They con- 


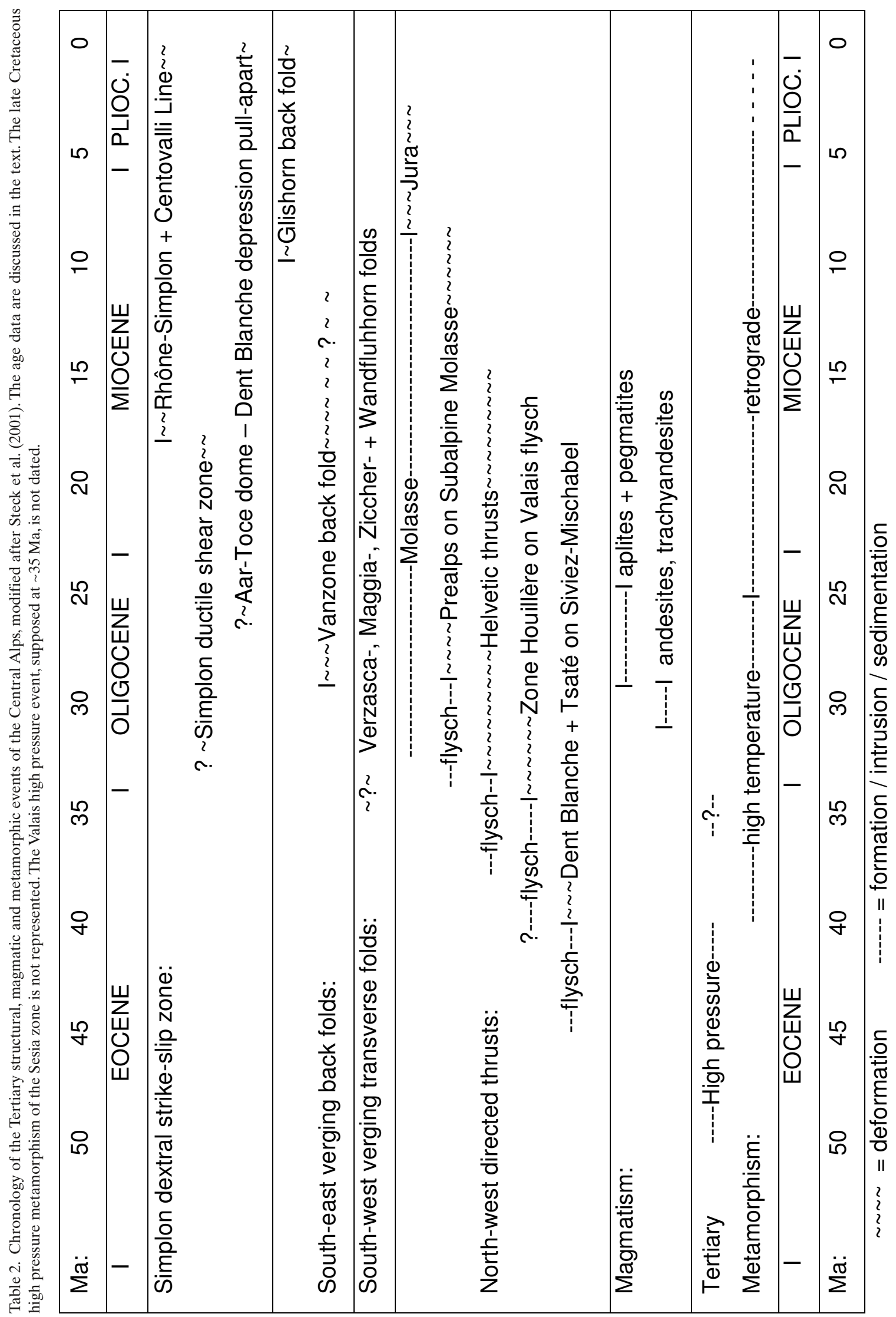




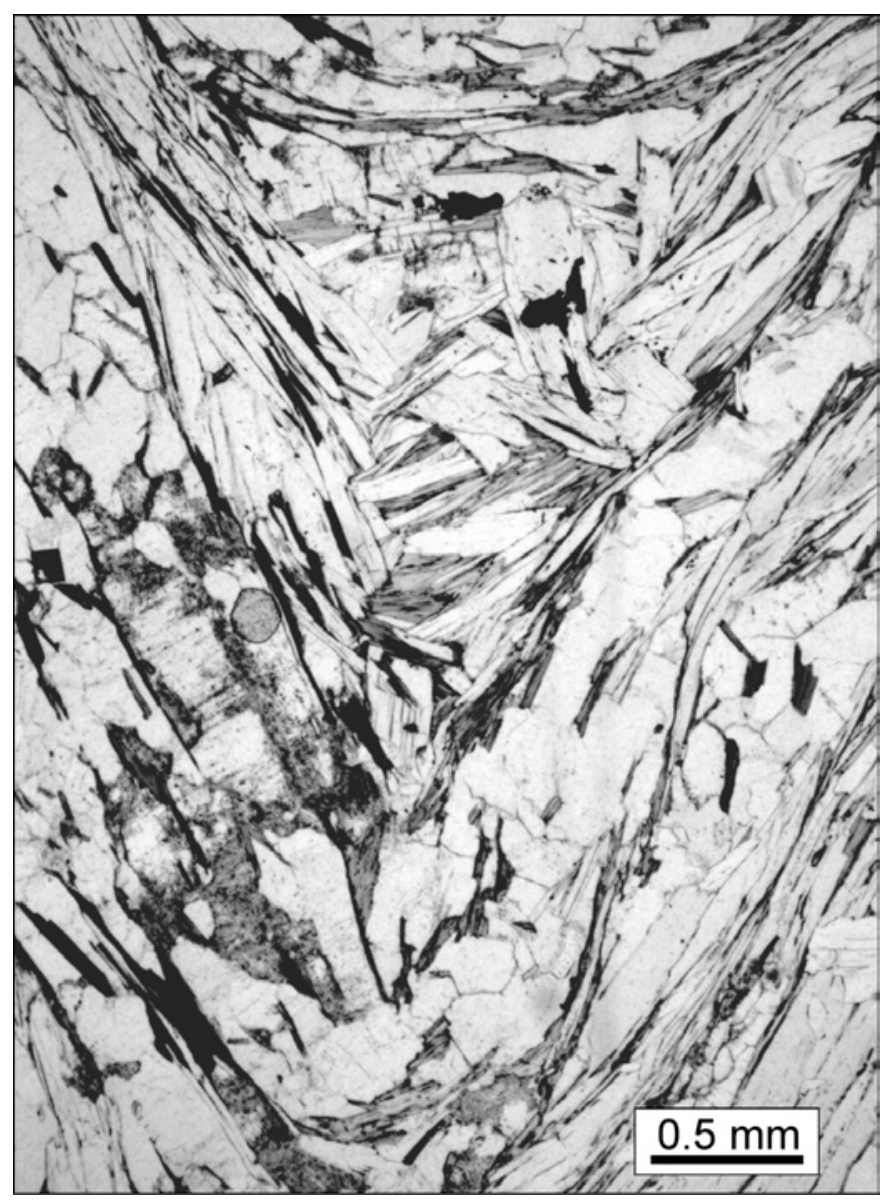

Fig. 15. Photomicrograph of a fold hinge of the Masera syncline (sample AS0604; Viggezzo Valley road to the E of Masera), that was formed under greenschist facies conditions. Muscovite, biotite and chlorite are folded and kinked during this phase of folding, while the quartz and albite crystallised with a polygonal texture, indicating temperatures estimated of about 350 $450{ }^{\circ} \mathrm{C}$.

tain diagenetic to anchizone mineral assemblages of quartz, $\mathrm{K}$ feldspar, albite, chlorite, epidote, prehnite, laumontite and clay minerals. The latter are illite, smectite, associated with mixedlayer illite/smectite and chlorite/smectite. The diagenetic and anchizonal illites ( $<2 \mu \mathrm{m}$ fraction) of 9 fault gouge samples were dated by the K-Ar method of $4-14 \pm 0.2 \mathrm{Ma}$, indicating a late Miocene to earliest Pliocene age for late movements on the Centovalli line (Surace 2004). Zwingmann \& Mancktelow (2004) determined ages of 8.3 to 9.1 Ma for gouges of the Centovalli fault.

The dextral strike-slip displacement on the Centovalli fault is not estimable; it may be in the order of some kilometer.

\section{The Insubric line}

The Insubric line forms the boundary between the high grade late Cretaceous and Tertiary metamorphic rocks of the Central Alps to the $\mathrm{N}$ and the poly-cyclic Paleozoic basement of the
Southern Alps, with a Tertiary greenschist to anchizonal metamorphic overprint at its northern boundary with the Insubric line (Steck \& Tièche 1976; Hurford 1986; Schmid et al. 1989; Hunziker et al. 1989; Steck et al.2001). The Insubric line is composed of two branches, each with a different structural history (Plate 1, Fig. 1).

1. The NE-striking Canavese line to the $\mathrm{W}$ of the Lago Maggiore (Locarno) and

2. The E-striking Tonale line to the E of Locarno.

\section{The Canavese line}

The Canavese line represents a tectonic boundary with a long lasting history (Schmid et al. 1989; Steck \& Hunziker 1994). A zone of Permian greywacke, Triassic marbles and dolomites, intruded by basaltic dikes and Liassic dark grey graphitic siliceous marbles are testimony to a Permo-Jurassic marine basin originally situated between the Austroalpine basement-block and the Southern Alpine basement of the Adriatic margin (Steck et al. 2001, Ferrando et al. 2004). These Canavese sediments were accreted to the Ivrea margin, before their Alpine greenschistfacies overprint. The Sesia zone was subducted, overprinted by a high-pressure metamorphism, extruded and accreted to the Adriatic margin, with creation of mylonite zones on its northern and southern border, during the Late Cretaceous to Early Tertiary (Oberhänsli et al. 1985; Hunziker et al. 1992, Ruffet et al. 1997; Rubatto et al. 1999; Babist et al. 2006). The Alpine closure of the Piemont ocean and continental collision occurred in the Early Eocene. The NW-verging Alpine nappe stack was deformed after its formation by huge S-verging folds together with the Southern Alps of the hanging wall. The Canavese line acted as an inverse fault with a steep stretching lineation XIII during this Oligocene phase of back folding (Argand's 1916, Insubric phase), creating a thousand meter wide southern mylonite zone of the Sesia zone (schisti di Fobella e Rimella; Steck 1990). The so-called schisti di Fobella and Rimella represent an Alpine mylonite zone that comprises also Canavese sediments and mylonites of the joining Ivrea zone border. This phase is of the age of the Oligocene, $30 \mathrm{Ma}$ porphyritic dikes. The SEdirected back thrusting phase was accompanied and followed by the W-directed under thrust movement of the Adriatic indenter, creating a younger W-directed stretching lineation XIV, in the mylonites of the Canavese fault zone (Steck 1990). The most recent movements, with a late uplift of the Southern Alps, occurred on more discrete normal faults in the Canavese fault zone (Steck \& Tièche 1976). The apatite fission track data of Fazis (2004) from the Toce valley along transect across the Canavese line indicate that north-side down normal fault movements on this major fault were active during the last $2 \mathrm{Ma}$.

\section{The Tonale line}

The Tonale line is a younger vertically dipping and E-striking, dextral strike-slip fault situated to the E of Locarno. It cuts the 

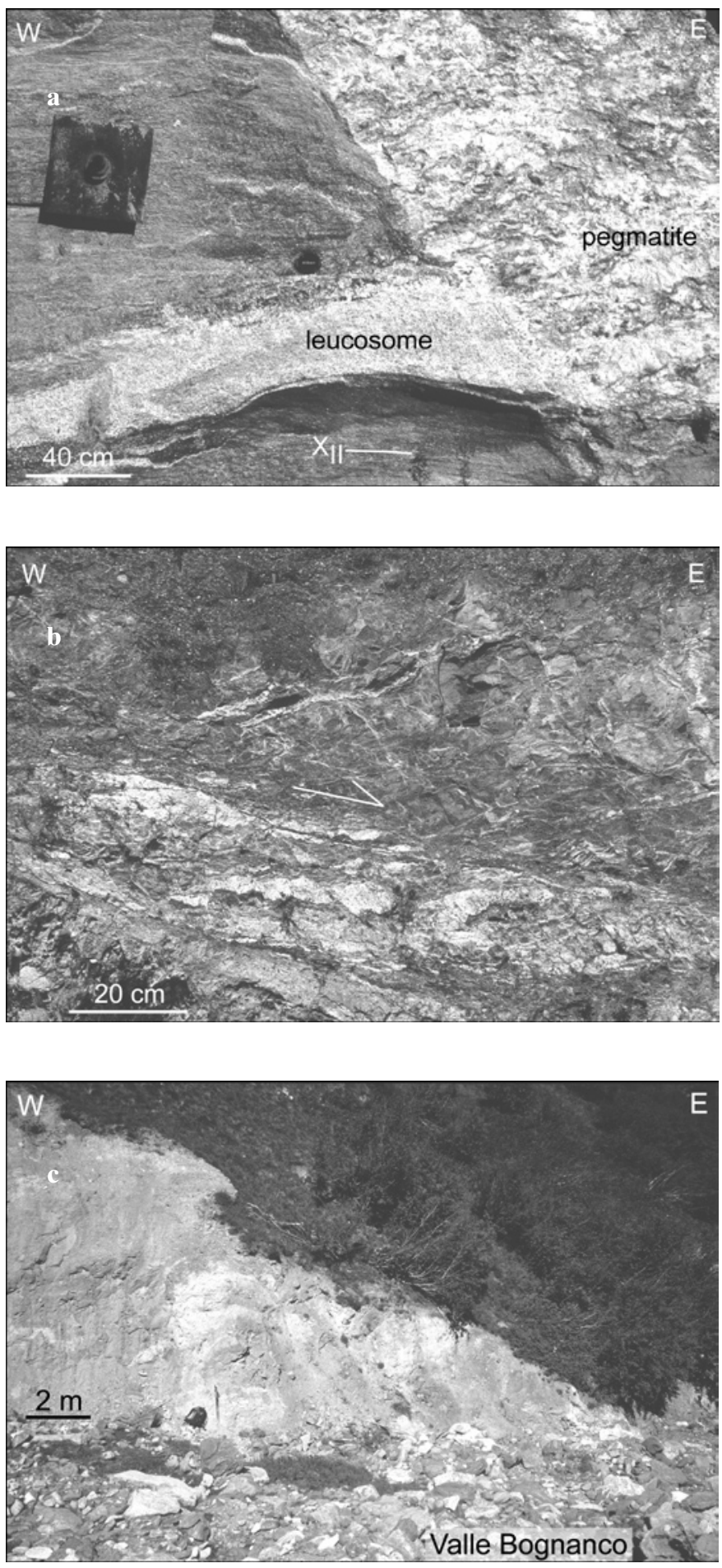

Fig. 16. a) A Variscan migmatite leucosome with its Tertiary amphibolite facies stretching lineation XII is cut by a 26 Ma pegmatite (Corcapolo, Centovalli road; Pegmatite, US-91-A3: $26.5 \pm 0.6 \mathrm{Ma}$ U-Pb monazite age, $24.7 \pm 0.3 \mathrm{Ma}$ $\mathrm{U}-\mathrm{Pb}$ xenotime age; aplitic leucosome, US-92-A4: ca $280 \mathrm{Ma}$, U-Pb zircon age, Romer et al. 1996; Schärer et al. 1996). b) Dextral cataclastic strike-slip structures in banded Orselinagneiss (E-border of Camedo village, Centovalli road). c) Non cohesive cataclastic breccia with upto meter size blocks and fault gauge or "kakirite" (Svenonius 1892 in Higgins 1971) of Bognanco fault, Alpe Agroso, coordinates: 653500/107200).

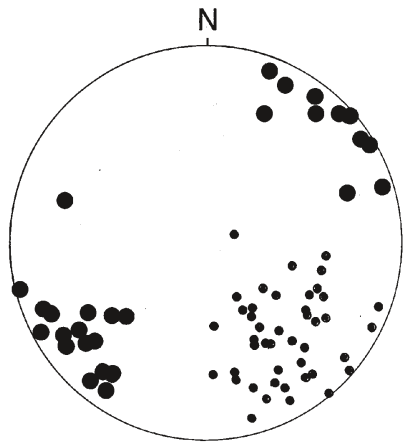

- $\quad$ main schistosity plane

- $\mathrm{X}_{11}$ - stretching lineation

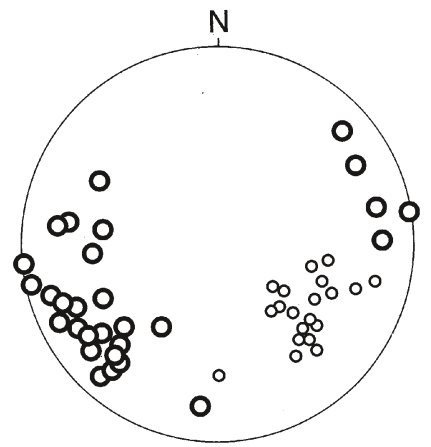

- younger shear plane

- $X_{I V}$ - stretching lineation

\section{Palagnedra - Bordei}

Fig. 17. Equal area stereoplots (lower hemisphere) of the structures of the ductile Simplon shear zone (main schistosity and stretching lineation XII), and the younger Centovalli strike-slip zone (stretching XIV) from the Palagnedra - Bordei road.

older back-fold structures of the Oligocene Canavese (Insubric) line (Berger et al. 1996; Davidson et al. 1996; Handy et al. 2005). The Tonale fault determines the eastern end of the Zermatt - Saas Fee, Monte Rosa, Sesia and Ivrea zones. The Tonale line acted in a later stage, also as a N-dipping normal fault, causing relative exhumation of the Southern Alps (e.g. Schmid et al. 1989). The dextral strike-slip and late normal fault structures of the Tonale line continue to the $\mathrm{W}$ in the Centovalli line.

\section{Alpine tectonic considerations}

The tectonic evolution of the Simplon massif and central Alps is documented in Figs. 18-19 and Table 2. Table 2 summarises the structural, metamorphic and sedimentary evolution of the central Alps since continental collision, some $50 \mathrm{Ma}$ ago. Table 2 was modified after Tableau 3 in Steck et al. (2001) and Fig. 14 in Keller et al. (2005). The beginning of the formation of the Alpine range is dated by the Eocene 50-40 Ma high-pressure metamorphism of the Piemont oceanic crust (e.g. Amato et al. 1999; Lapen et al. 2003; Mahlen et al. 2005) and the successive deposition of Eocene and Early Oligocene flysch sediments that accompanied the NW-migrating Alpine nappe emplacement (Steck et al. 2001). The NW-SE cross-sections of Fig. 18 document the successive nappe detachment and phases of conjugate backfolding during the SE-directed underthrusting of the European plate below the Adriatic plate, since $34 \mathrm{Ma}$. The block diagram of Fig. 1 and the structural map of the Central Alps (Plate 1) illustrate the complex three-dimensional geometry of the Zone of Alpine continental collision. The map-sketch of Fig. 19 suggests a possible path of the Adriatic promontory relative to Europe during the Alpine continental collision (stippled line). The analysis of the interference structures of the Simplon massif allows the distinction of a succession of movements of convergence, dextral strike-slip and transpression. The 


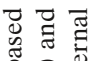

응.

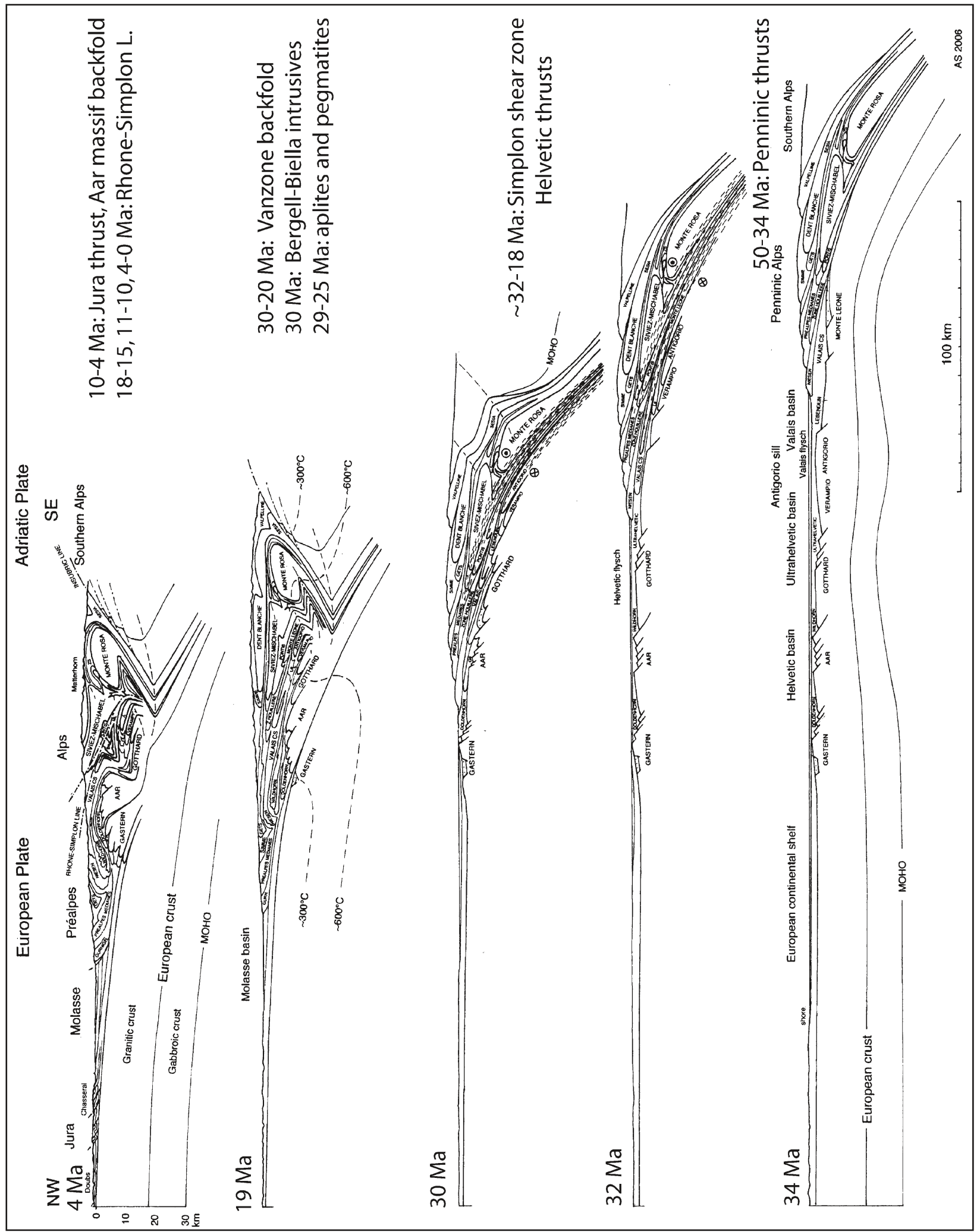

$\sum_{\triangleleft}^{\pi}=0$

त

.

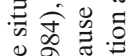

등

要 응

w क

출

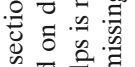

.ॅू

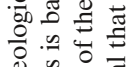

品言魚

등

定记

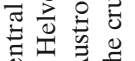

U च

छ ฮ

它 윰 自

힐

흡 콜

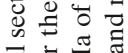

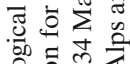

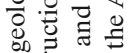

혼

.

प斤

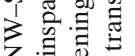

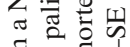

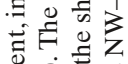

응

늘 웅

흥 흘

एँ $\div$

的密

ปั่

금

을 च

उ

할

光跑

渮泀

แै

究莍

$\infty$ o

玨 


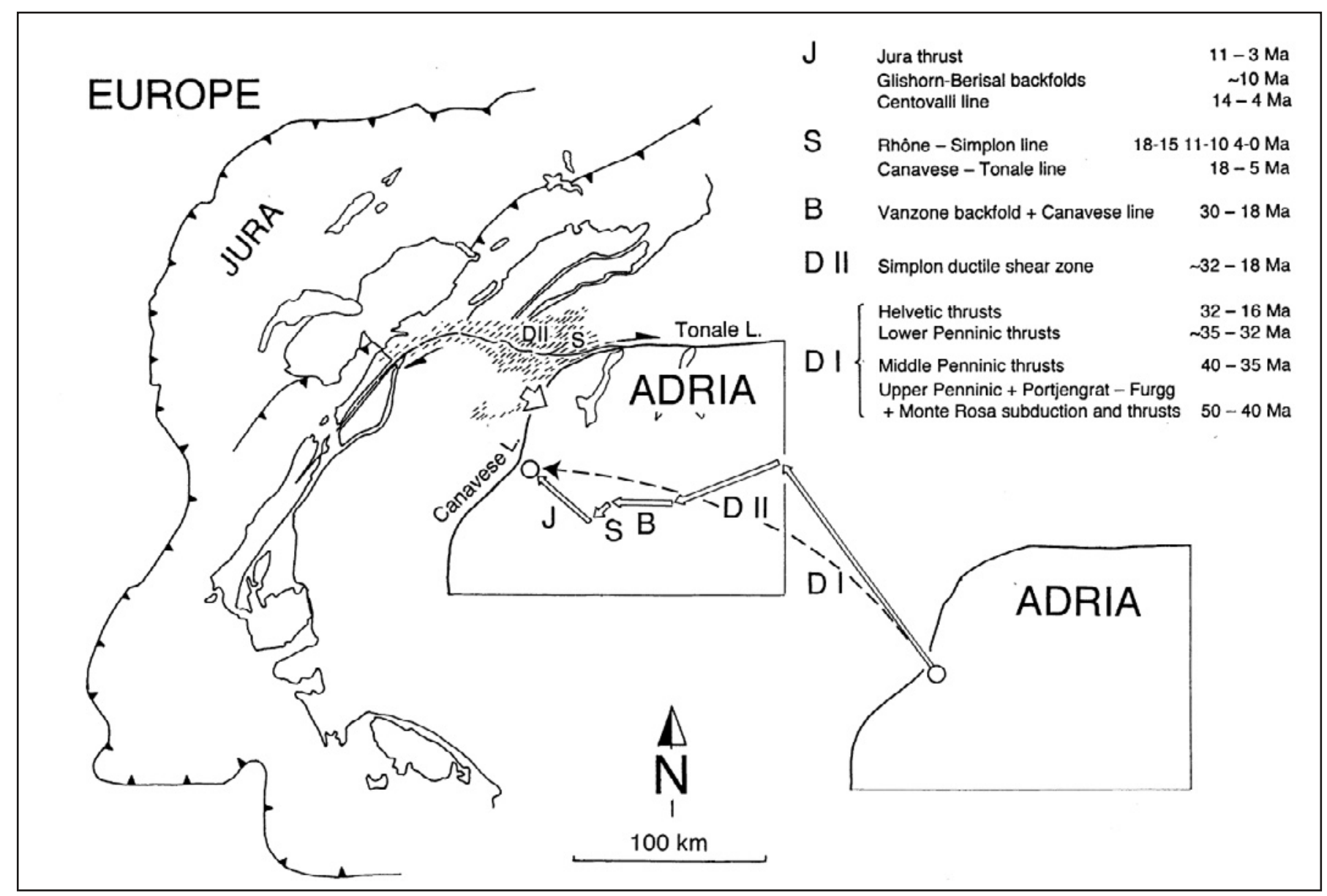

Fig. 19. Directions of shortening and approximate trajectory (stippled line) of the Adriatic plate relative to Europe during the Cenozoic continental collision and formation of the Alps between $50 \mathrm{Ma}$ and the present (after Steck 1984,1990, modified). The length of the vectors can only be roughly estimated. A precise quantification of the shortening in the Penninic nappes is actually not possible, because of the important ductile rock deformation and the material that is missing by erosion and subduction.

displacement vectors are constructed parallel to the observed stretching lineations (XI-XIV) of shear zones or perpendicular to great fold structures, knowing that the real displacement directions may be different and form an oblique angle with these structures. The lengths of the vectors are arbitrary. Quantitative measurements are only available for the thin-skinned Jura and Helvetic thrusts (Laubscher 1961, 1965; Burkhard 1990; Burkhard \& Sommaruga 1998; Steck 1984), for the Simplon line (Hunziker 1969; Hunziker \& Bearth 1969; Mancktelow 1985) and the detachment on the Simplon ductile shear zone (Steck, 1984). A precise measurement or estimation of the main Ultra-Helvetic and Penninic displacements is actually not possible, because of the strong internal rock deformation and the material that is missing by erosion and subduction. Estimations of the shortening in the Penninic nappes were proposed in the model of Schmid et al. (1999) and Schmid \& Kissling (2000). In this study it is argued that internal rock deformation and loss of material by erosion or subduction are not negligible factors. Therefore models mentioned before may underestimate shortening. Different deformations occurred simultaneously as indicated on the timetable on Fig. 19 and Table 2. The NW-oriented thrusting (DI) of the Helvetic nappes, the SW-directed detachment and dextral movements (DII) in the Simplon ductile shear zone and the SE-verging Vanzone back folding are of the same period of 32-16 Ma. The NW-directed Jura thrust was contemporaneous with the SE-verging Glishorn-Berisal backfolding and SW-extension on the Rhone-Simplon line (Steck et al. 2001). Considering this observations, it is suggested that the Adria displacement relative to Europe was not a zigzag as proposed earlier (Steck 1990), but probably a more rectilinear NW- to WNW-directed convergence path (stippled line on Fig. 19), that was accommodated by shortening in different directions.

\section{Conclusion}

The Simplon massif and the Lepontine gneiss dome represent a unique region in the western Alpine arc, where deformation 
structures of its deepest tectonic level are exposed. The complex, three dimensional structures of the Simplon massif and Lepontine Alps result from the continental collision of two plate boundaries with contrasting geometry: the European plate and the Adriatic indenter. Deformation structures within the Simplon massif and Lepontine gneiss dome reflect the rock rheology related change of structural style between the cold and rigid tectonic lid and the deep seated hot and ductile stage of the Alps. The metamorphic rocks of the Lepontine gneiss dome registrated during the Alpine dextral transpression and their uplift and erosion the retrograde ductile structural evolution between 40-25 Ma in amphibolite metamorphic grade to Late Miocene anchizonal brittle structures. Structural analyses and paleogeographic considerations suggest that during continent-continent collision and formation of the Central Alps, the Adriatic promontory drifted in a NW- to WNW-direction relative to Europe (Fig. 18, stippled line on Fig. 19; Laubscher 1971; Steck 1980, 1984, 1987, 1990; Gourlay \& Ricou 1983; Gourlay 1984) probably accompanied by an anti-clockwise rotation of the Adriatic indenter (Steck 1984, 1990; Steck et al. 2001, Schmid \& Kissling 2000). The simultaneous divergent movements of thrusting and shortening in front of the Adriatic indenter, documented by the interference structures of the Simplon massif and the Lepontine gneiss dome, are in agreement with the geometry of the fan-shaped N-, NW- and W-directed frontal thrusts of the arc of the Western Alps.

\section{Acknowledgments}

Mark Handy, Niel Mancktelow and an anonymous reviewer are thanked for their critical reading of the manuscript. J. Allaz, V. Baudraz, L. Baumgartner, F. Bussy, E. Carrupt, A. Colombi, M. Cosca, E. Dolivo, M. Eichenberger, J.-L. Epard, A. Escher, F. Genier, J.-G. Hammerschlag, J. Hunziker, X. Maeder, H. Masson, H.-R. Pfeifer, M. Robyr, M. Schlup, I. Surace, Ph. Thélin, J.-Cl. Vannay and many others of the Lausanne Alpine working group contributed to this study by fruitfull discussions on the outcrop and in the laboratory. Laurent Nicod furnished excellent thin and polished sections of rocks.

\section{REFERENCES}

Amato, J.M., Johnson. C.M., Baumgartner, L.P. \& Beard, B.L. 1999: Rapid exhumation of the Zermatt-Saas ophiolite deduced from high precision $\mathrm{Sm}-\mathrm{Nd}$ and $\mathrm{Rb}-\mathrm{Sr}$ geochronology. Earth and Planetary Science Letters $171,425-438$.

Argand,E.1911: Les nappes de recouvrement des Alpes Pennines et leurs prolongements structuraux. Beiträge zur Geologischen Karte der Schweiz [N.F.] 31, 26pp.

Argand, E. 1916: Sur l'arc des Alpes Occidentales. Eclogae Geologicae Helvetiae 14, 145-204.

Aramowicz, A. 2007: High exhumation rates in the Aar massif reveled by the zircon $(\mathrm{U}-\mathrm{Th}) / \mathrm{He}$ thermochronology. $5^{\text {th }}$ Swiss Geoscince Meeting, Geneva 2007, Abstract volume p. 14.

Aubry, D. 1984. Les gneiss mylonitisés le long de la ligne Rhône-Simplon. Diploma thesis. University of Lausanne.

Babist, J., Handy, M.R., Konrad-Schmolke, M. \& Hammerschmidt, K. 2007: Precollisional, multistage exhumation of subducted continental crust: The Sesia Zone, western Alps. Tectonics 26, doi:10.1029/2005TC001927.

Baer, M., Deichmann, N., Braunmiller, J., Husen, S., Fäh, D., Giardini, D., Kästli, P., Kradolfer, U. \& Wiemer, S. 2004. Eclogae Geologicae Helvetiae 98/3, 407-418.
Bagnoud, H., Wernli, R. \& Sartori, M. 1998: Découverte de foraminifers planctoniques paléogènes dans la zone de Sion-Courmayeur à Sion (Valais, Suisse). Eclogae Geologicae Helvetiae 91, 421-429.

Barberi, F. \& Scandoni, P. 1986: Structural Model of Italy, 1:500'000. CNR Italia.

Barnicoat, A.C., Rex, D.C., Guise, P.G. \& Cliff, R.A. 1995: The timing of and nature of greenschist facies deformation and metamorphism in the upper Pennine Alps. Tectonics 14, 279-293.

Baudin, T. \& Marquer, D. 1993: Tertiary extensional structures in the Penninic zone of the Central Alps (Switzerland - Grisons). In: M. Séranne \& J. Malavieille (Eds.): Late orogenic extension in mountain belts. Montpellier meeting, Abstracts volume, BRGM n ${ }^{\circ} 219: 18-19$.

Baudraz,V.F.2000: Géologie et mineralogy du Nord de la Zone du Portjengrat (Saastal, Valais). DEA Université de Lausanne.

Bearth, P. 1956a: Geologische Beobachtungen im Grenzgebiet der lepontinischen und penninischen Alpen. Eclogae Geologicae Helvetiae 49, 279-290.

Bearth, P. 1956b: Zur Geologie der Wurzelzone östlich des Ossolatales. Eclogae Geologicae Helvetiae 49, 267-278.

Bearth, P. 1957: Die Umbiegung von Vanzone (Valle Anzasca). Eclogae Geologicae Helvetiae 50,161-170.

Bearth, P. 1967: Die Ophiolite der Zone Zermatt-Saas-Fee. Beiträge zur Geologischen Karte der Schweiz [N.F.] 132.

Beccaluva, L., Bigioggero, B., Chiesa, S., Colombo, A., Gatto, G.O., Gregnanin, A., Montrasio, A., Piccirillo, E.M. \& Tunesi, A. 1983: Post collisional orogenic dike magmatism in the Alps. Memorie Societa Geologica Italia 26, 341-359.

Becker, H. 1993: Garnet peridotite and eclogite Sm-Nd mineral ages from the Lepontine dome (Swiss Alps): new evidence for Eocene high pressure metamorphism in the Central Alps. Geology 21, 599-602.

Berger, A., Rosenberg, C. \& Schmid, S.M. 1996: Ascent, emplacement and exhumation of the Bergell pluton within the Southern Steep Belt of the Central Alps. Schweizerische Mineralogisch und Petrographische Mitteilungen 76, 357-382.

Berger, A. \& Mercolli, I. 2006: Tectonic and Petrographic Map of the Central Lepontine Alps. Carta geologica speciale N. 127, 1:100'000, Federal Office of Topography, Ch-4084 Wabern.

Berger, A., Mercolli, I. \& Engi, M. 2005: The central Lepontine Alps: Explanatory notes accompaning the tectonic-geological map sheet Sopra Ceneri (1:100'000). Schweizerische Mineralogisch und Petrographische Mitteilungen 85, 109-146.

Bergerat, F. 1987: Paléo-champs de contrainte tertiaires dans la plate-forme européenne au front de l'orogène alpin. Bulletin de la Société géologique de France, 8, 611-620.

Bernoulli, D., Manatschal G., Desmurs, L. \& Müntener, O. 2003: Where did Gustav Steinmann see the trinity? Back to the roots of an Alpine ophiolite concept. Geological Society of America Special Paper 373, 93 110.

Bertrand, M. 1884: Rapports des structures des Alpes de Glaris et de bassin houiller du nord. Bulletin de la Société Géologique de France 3/12,318330 .

Bigioggero, B., Borian, A., Colombo A., Ferrara, G., Tunesi, A. \& Tonarini, S. 1981: Eta et caratteri petrochimici degli ortogneiss della zona MoncuccoOrselina nell'area ossolana. Rendiconti della Societa Italiana di Mineralogia e Petrologia 38, 207-218.

Bigioggero, B., Boriani, A., Colombo, A. \& Gregnanin, A. 1981. Carta geologica delle Valli Vigezzo, Fenecchio e basso Isorno. 1:25 000. C.N.R.-Centro di studio per la stratigrafia e petrografia delle Alpi Centrali - Milano. S.E.L.CA. via dei Servi, 14, Firenze.

Bill, M., Bussy, F., Cosca, M., Masson, H. \& Hunziker, J. 1997: High precission $\mathrm{U}-\mathrm{Pb}$ and $40 \mathrm{Ar} / 39 \mathrm{Ar}$ dating of an Alpine ophiolite (Gets nappe, French Alps). Eclogae Geologicae Helvetiae 90, 43-54.

Bousquet, R., Goffé, B., Henry, P., Le Pichon, X. \& Chopin, C. 1997: Kinematic. Thermal and petrological model of the Central Alps: Lepontine metamorphism in the Upper crust and eclogitisation of the lower crust. Tectonophysics 273, 105-127.

Bousquet, R., Goffé, B., Vidal, O., Oberhansli, R. \& Patriat, M. 2002: The tectonometamorphic history of the Valaisan domain from the Western Alps 
to the Central Alps: new constraints on the evolution of the Alps. Geological Society of America Bulletin 114, 207-225.

Brouwer, F.M., Burri, T., Engi, M. \& Berger, A. 2005: Eclogite relicts in the Central Alps: PT-evolution, Lu-Hf ages and implications for formation of tectonic mélange zones. Schweizerische Mineralogische und Petrographische Mitteilungen 85, 147-174.

Bucher, S. Schmid, S.M., Bousquet, R. \& Fügenschuh, B. 2003: Late-stage deformation in a collisional orogen (Western Alps): nappe refoldimg, backthrusting or normal faulting? Terra Nova 15, 109-117.

Burkhard, M. 1990: Aspects of the large-scale Miocene deformation in the most external part of the Swiss Alps (Subalpine Molasse to Jura fold belt). Eclogae Geologicae Helvetiae 83/3, 559-584.

Burkhard, M. \& Sommaruga, A. 1998: Evolution of the western Swiss Molasse basin: structural relations with the Alps and the Jura belt. In: Mascle, A., Puigdefàbregas, A., Luterbacher, H.P. \& Fernàndez, M. (Eds.): Cenozoic Foreland Basins of Western European Geological Sciences Special Publication 134, 279-298.

Burri, T. 2005: From high-pressure to migmatisation: on orogenic evolution of the Southern Lepontine (Central Alps of Switzerland/Italy). Ph.D. thesis, Bern University.

Bussy, F., Eichenberger, M., Giroud, N., Masson, H., Meilhac, C. \& Presniakov, S. 2005: Early Carboniferous age of the Versoyen magmatism and consequences: Non-existing of a "Valais ocean". Abstract Volume, $3^{\text {rd }}$ Swiss Geosciences Meeting, $18^{\text {th }}-19^{\text {th }} 11,2005$, Zürich, p.58.

Carrupt, E. 2002: Geological and mineralogical study of the High Val Formazza - Binntal area (Central Alps). Ph.D. thesis, Lausanne University.

Cartwright, I. \& Barnicoat, A.C. 2002: Petrology, geochronology, and tectonics of shear zones in the Zermatt-Saas and Combin zones of the Western Alps. Journal of metamorphic Geology 20, 263-281.

Colombi, A. 1989: Métamorphisme et géochimie des roches mafiques des Alpes ouest-centrales (géoprofil Viège - Domodossola - Locarno). Mémoires de géologie (Lausanne) 4 .

Colombi, A., Kobe, H. \& Pfeifer, H.R. in press: Map sheet 1312 Locarno, Atlas géologique Suisse 1:25'000, Federal Office of Water and Geology.

Dal Piaz, G.V., Del Moro, A., Martin, S. \& Venturelli, G. 1988: Post-Collisional Magmatism in the Ortler-Cevedale Massif (Northern Italy). Jahrbuch der Geologischen Bundesanstalt, Wien 131, 533-551.

Davidson, C., Rosenberg, C. \& Schmid, S.M. 1996: Synmagmatic folding of the base of the Bergell pluton, Central Alps. Tectonophysics 265, 213-238.

Debelmas, J. \& Kerckove, C. 1980: Les Alpes franco-italiennes. Géologie Alpine, 56, 21-58.

Debelmas, J., Oberhauser, R., Sandulescu, M. \& Trümpy, R. 1980: L'arc alpinocarpathique. In: J. Aubouin, J. Debelmas and M. Latreille (Eds.): Geologie des chaînes alpines issues de la Téthys. Mémoires du B.R.G.M., 115, 86-95.

Delaloye, M, Grichting, A., Meisser, N., Pflug, L., Steck, A. \& Tissières, P. 2005 : Simplon: Histoire - Géologie - Minéralogie. Fondation Bernard et Suzanne Tissières, Martigny, $128 \mathrm{p}$.

Dolivo, E. 1982: Nouvelles observations structurales au SW du massif de l'Aar entre Visp et Gampel. Ph.D. thesis, Université de Lausanne.

Duchène, S., Blichert-Toft, J., Luais, B., Télouk, P., Lardeaux, J.-M. \& Albarède, F. 1997: The Lu-Hf dating of garnets and the ages of the Alpine high-pressure metamorphism. Nature 387, 586-588.

Engi, M., Scherrer, N.C. \& Burri, T. 2001: Metamorphic evolution of pelitic rocks of the Monte Rosa nappe: Constraints from petrology and single grain monazite age data. Schweizerische Mineralogische und Petrographische Mitteilungen 81, 305-328.

Engi, M., Berger, A. \& Roselle, G. 2001: The role of the tectonic accretionary channel in collisional orogeny. Geology 29, 1143-1146.

Engi, M., Bousquet, R. \& Berger A. 2004: Explonatory notes to the map: Metamorphic structure of the Alps, Central Alps. Mitteilungen der Österreichischen Mineralogischen Gesellschaft 149,157-173.

Engi, M., Todd, C.S. \& Schmatz, D.R. 1995: Tertiary metamorphic conditions in the eastern Lepontine Alps. Schweizerische Mineralogische und Petrographische Mitteilungen 75, 347-369.

Epard, J.-L. 1986: Le contact entre le socle du Mont-Blanc et la zone de Chamonix: implications tectoniques. Bulletin de la Société Vaudoise des Sciences naturelles 78/2, 225-245.
Epard, J.-L. 1990: La nappe de Morcles au sud-ouest du Mont-Blanc. Mémoire de géologie (Lausanne) 8.

Epard, J.-L. \& Escher, A. 1996: Transition from basement to cover: A geometric model. Journal of structural Geology 18, 533-548.

Escher, A. \& Beaumont, C. 1997: Formation, burial and exhumation of basement nappes at crustal scale: A geometric model based on the western Swiss-Italian Alps. Journal of structural Geology 19, 955-974.

Escher, A., Hunziker, J., Marthaler, M., Masson, H., Sartori, M. \& Steck, A. 1997: Geologic framework and structural evolution of the western SwissItalian Alps. In: Pfiffner, O.A., Lehner, P., Heitzmann, P., Mueller, S. \& Steck, A. (Eds.): Deep Structure of the Swiss Alps: Results of NRP 20, 205-221. - Birkhäuser Verlag Basel.

Escher, A., Masson, H. \& Steck, A. 1988: Coupes géologiques à travers la partie centrale des Alpes occidentales suisses. Rapports géologiques du Service hydrologique et geologique national Suisse 2,1-11.

Escher, A., Masson, H. \& Steck, A. 1993: Nappe geometry in the Western Swiss Alps. Journal of structural Geology 15, 501-509.

Fazis, Y. 2004: Finding faults! - A normal fault component in the Insubric line? New apatit fission track ages in the Val d'Ossola / Alps of Italy. $2^{\text {nd }}$ Swiss Geoscience Meeting, abstracts, Lausanne, 2004.

Ferrando, S., Bernoulli, D. \& Compagnoni, R. 2004: The Canavese zone (internal Western Alps): a distal margin of Adria. Schweizerische Mineralogische und Petrographische Mitteilungen 84, 237-256.

Florineth, D. \& Froitzheim, N. 1994: Transition from continental to ocean basement in the Tasna nappe (engadin window, Graubünden, Switzerland): evidence for Early Cretaceous opening of the Valais ocean. Schweizerische Mineralogische und Petrographische Mitteilungen 74, 437-448.

Frank, E. 1983: Alpine metamorphism of calcareous rocks along a cross-section in the Central Alps: occurence and breakdown of muscovite, margarite and paragonite. Schweizerische Mineralogische und Petrographische Mitteilungen 63, 37-93.

Froitzheim, N. 1992: Formation of recumbent folds during synorogenic crustal extension (Austroalpine nappes, Switzerland). Geology 20, 923-926.

Froitzheim, N., Schmid, S.M. \& Frey, M. 1996: Mesozoic Paleogeography and the timing of eclogite-facies metamorphism in the Alps. Eclogae Geologicae Helvetiae 89, 559-612.

Gebauer, D., 1999. Alpine Geochronology of the Central and Western Alps. Schweizerische Mineralogisch und Petrographische Mitteilungen 79: 191-208.

Geologische Karte der Schweiz, 1:500'000, 2005: Federal Office for Water and Geology, Bern, Switzerland.

Genier, F. \& Epard, J.-L. 2007: The Fry method applied to an augen orthogneiss: Problems and results. Journal of structural Geology 29, 209-224.

Genier, F., Epard, J.-L., Bussy, F. \& Magna, T. 2008: Lithostratigraphy and U$\mathrm{Pb}$ zircon dating in the overturned limb of the Siviez-Mischabel nappe; a new key for Middle Penninic nappe geometry. Swiss Journal of Geosciences 101/2.

Gerlach, H. 1869: Karte der Penninischen Alpen, 1:200'000.

Gerlach, H. 1883: 1. Heinrich Gerlach, sein Leben und Wirken. 2. Die Penninischen Alpen. 3. Bericht über den Bergbau im Kanton Wallis. Beiträge zur Geologischen Karte der Schweiz [N.F.] 27, 1-79.

Gidon, M. 1974: L'arc alpin a-t-il une origine tourbillonaire? Comptes Rendus de l'Academie des Sciences naturelles de Paris D, 278, 21-24.

Gourlay, P. 1984: La déformation alpine des massifs cristallins externes (MontBlanc, Aiguilles-Rouges, Belledonne) et celle de leur couverture mésozoïque (Alpes occidentales). Thèse Univ. Pierre et Marie Curie, Paris 6.

Gourlay, P. \& Ricou, L.E. 1983: Le jeu décrochant dextre tardif de la suture de Chamonix (Alpes françaises et suisses). Comptes Rendus de l'Academie des Sciences naturelles de Paris 296-Série II, 927-932.

Grasemann, B. \& Mancktelow, N. 1993: Two-dimensional thermal modelling of normal faulting: the Simplon Fault Zone, Central Alps, Switzerland. Tectonophysics 225, 155-165.

Grosjean, G., Sue, C. \& Burkhard, M. 2004: Brittle extension around the Simplon fault. Eclogae Geologicae Helvetiae 97, 33-46.

Grujic, D. \& Mancktelow, N.S. 1996: Structure of the northern Maggia and Lebendun nappes, Central Alps, Switzerland. Eclogae Geologicae Helvetiae $89,461-504$. 
Gubler, E., Kahle, H.G., Klingele, E., Müller, S. \& Olivier, R. 1981: Recent crustal movements in Switzerland and their geophysical interpretation Tectonophysics, 38, 297-315.

Hall, W.D.M. 1972: The structural and metamorphic history of the lower pennine nappes, Valle di Bosco, Ticino, Switzerland. Ph.D. Thesis, University of London.

Hammerschlag, J.G. 1985: Métamorphisme progressif dans la séquence quartzofeldspathique - Profil Aar-Bergell (Alpes centrales). Ph. D. Thesis, Université de Lausanne.

Hammerschmidt, K. \& Frank, E. 1991: Relics of high pressure metamorphism in the Lepontine Alps (Switzerland) - 40Ar/39Ar and microprobe analyses on white K-micas. Schweizerische Mineralogische und Petrographische Mitteilungen 71, 261-274.

Handy, M.R., Babist, J., Wagner, R., Rosenberg, C. \& Konrad, M. 1990: Decoupling and its relation to strain partitioning in continental lithosphere: insight from the Periadriatic fault system (European Alps). In: Gapais, D., Brun, J.P. \& Cobbold, P.R. (Eds.): Deformation Mechanisms, Rheology and Tectonics: from Minerals to the Lithosphere. Geological Society of London, Special Publications 243, 249-276.

Handy, M. \& Oberhänsli, R. 2004: Metamorphic structure of the Alps: Tectonometamorphic age map. Mitteilungen der Österreichischen Mineralogischen Gesellschaft 149, 201-226.

Hänny, R., Grauert, B. \& Soptrajanova, G. 1975: Paleozoic Migmatites affected by high-grade Tertiary metamorphism in the central Alps (Valle Bodengo, Italy). Contribution to Mineralogy and Petrology 51, 173-196.

Hayoz, P. \& Zuber, F. 1990: Das Simplonmassiv. Hydrogeologische Untersuchungen der unterirdischen thermalen Wasserzirkulationen und ihrer Zusammenhänge mit dem Eisenbahntunnel. Centre d'hydrogeologie, Université de Neuchâtel et Centre de recherches scientifiques fondamentales et appliquées de Sion.

Heim, Albert 1919-1922: Geologie der Schweiz, Bd. II: Die Schweizeralpen. Leipzig.

Heitzmann, P.1987: Evidence of Late Oligocene/Early Miocene backthrusting in the central alpine "root zone". Geodynamica Acta (Paris) 1, 183-192.

Higgins, M.W. 1971: Cataclastic rocks. Geological Survey Professional Paper 687, 97 p. Washington.

Hubbart, M.S. \& Mancktelow, N.S. 1989: Neogene strike-slip deformation in the western Alps. Eos (Transactions, American Geophysical Union) 70, 1310.

Hubbart, M.S. \& Mancktelow, N.S. 1992: Lateral displacement during Neogene convergence in the western and central Alps. Geology 20, 943-946.

Hunziker, J.C. 1969: Rb/Sr Altersbestimmungen aus den Walliser Alpen Hellglimmer- und Gesamtgesteinsalterswerte. Eclogae Geologicae Helvetiae $62,527-542$.

Hunziker, J.C. \& Bearth, P. 1969: Rb-Sr-Altersbestimmungen aus den Walliser Alpen. Biotitalterswerte und ihre Bedeutung für die Abkühlungsgeschichte der alpinen Metamorphose. Eclogae Geologicae Helvetiae 62, 205-222.

Hunziker, J.C., Desmons, J. \& Martinotti, G. 1989: Alpine thermal evolution in the central and western Alps. In: M.P. Coward, D. Dietrich \& R.G. Park (Editors), Alpine Tectonics. Geological Society of London, Special Publications 45, 353-367.

Hunziker, J.C, Desmons, J. \& Hurford, A.J. 1992: Thirty-two years of geochronological work in the Central and Western Alps: a review on seven maps. Mémoires de géologie (Lausanne) 13.

Hurford, A.J. 1986: Cooling and uplift patterns in the Lepontine Alps, southcentral Switzerland, and an age of vertical movement on the Insubric fault line. Contributions to Mineralogy and Petrology 93, 413-427.

Hurford, A.J., Flisch, M. \& Jäger, E. 1989: Unravelling the thermo-tectonic evolution of the Alps: a contribution from fission track analysis and mica dating. In: M.P. Coward, D. Dietrich \& R.G. Park (Eds.): Alpine Tectonics. Geological Society of London Special Publication 45, 369398.

Hurford, A.J. \& Hunziker, J.C. 1989: A revised thermal history of the Gran Paradiso Massif. Schweizerische Mineralogische und Petrographische Mitteilungen 69, 319-329.

Jaboyedoff, M., Baillifard, F. \& Derron, M.H. 2003: Preliminary note on uplift rates gradient, seismic activity and possible implications for brittle tecton- ics and rockslide prone areas: The example of western Switzerland. Bulletin de la Societé Vaudoise de Siences Naturelles 88, 401-420.

Jaboyedoff, M., Béglé, P. \& Lobrinus, S. 1996: Stratigraphie et evolution structurale de la zone de Furgg, au front de la napped u Mont-Rose. Bulletin de la Societé Vaudoise de Siences Naturelles 84, 191-210.

Jäger, E., Niggli, E. \& Wenk, E. 1967: Rb-Sr Altersbestimmungen an Glimmern der Zentralalpen. Beiträge zur Geologischen Karte der Schweiz [N.F.] 134, $67 \mathrm{p}$.

Jenny, H., Frischknecht, G. \& Kopp, J. 1923: Geologie der Adula. Beiträge zur Geologischen Karte der Schweiz [N.F.] 51, 123 p.

Kahle, H.G., Geiger, A., Bürki, B., Gubler, E. Marti, U. Wirth, B., Rothacher, M, Gurtner, W., Beutler, G., Bauersima, I. \& Pfiffner, O.A. 1997: Recent crustal movements, geoid and density distribution: contribution from integrated satellite and terrestrial measurements. In: Pfiffner, O.A., Lehner, P., Heitzmann, P., Mueller, S. \& Steck, A. (Eds.): Deep structure of Swiss Alps: Results of NRP 20, 251-259, Birkhäuser Verlag, Basel.

Keller, F. 1968: Mineralparagenesen und Geologie der Campo Tencia-Pizzo Forno-Gebirgsgruppe. Beiträge zur Geologischen Karte der Schweiz [N.F.] 135, $71 \mathrm{p}$.

Keller, F., Wenk, E., Bianconi, F. \& Hasler, P. 1980: P. Campo Tencia, Geol. Atlas Schweiz, 1:25'000, Atlasblatt 73, Kümmerely \& Frey, Bern.

Keller, L.M., Fügenschuh, B., Hess, M., Schneider, B. \& Schmid, S.M. 2006: Simplon fault zone in the western and central Alps: Mechanism of Neogene faulting and folding revisited. Geology 34, 317-320.

Keller, L.M., Hess, M., Fügenschuh, B. \& Schmid, S.M. 2005: Structural and metamorphic evolution SW of the Simplon line. Eclogae Geologicae Helvetiae 98, 19-49.

Knup, P. 1958: Geologie und Petrographie des Gebietes zwischen Centovalli-Valle Vigezzo und Onsernone. Schweizerische Mineralogische und Petrographische Mitteilungen 38, 83-236.

Konrad-Schmolke, M. Babist, J., Handy, M.R.\& O'Brian, P.J. 2006: The physicochemical properties of a subducted slab from garnet zonation patterns (Sesia zone, Western Alps). Journal of Petrology 47/11, 2123-2148.

Kröner S. 2000: Analyse minéralogique et tectonique dans la region FusioValle Maggia (Tessin, Suisse). Master thesis, Université de Lausanne.

Lacassin, R. 1989: Plate-scale kinematics and compatipility of crustal shear zones in the Alps. In: M.P. Coward, D. Dietrich \& R.G. Park (Eds.): Alpine Tectonics. Geological Society of London Special Publication 45, 339-352.

Lapen, T.J., Johnson, C.M., Baumgartner, L.P., Mahlen, N.J., Beard, B.L. \& Amato, J.M. 2003: Burial rates during prograde metamorphism of an ultrahigh-pressure terrane: an example from Lago di Cignana, weatern Alps, Italy. Earth Planetary Science Letters 215, 57-72.

Laubscher, H.P. 1961: Die Fernschubhypothese der Jurafaltung. Eclogae Geologicae Helvetiae 52, 221-282.

Laubscher, H.P. 1965: Ein kinematisches Model der Jurafaltung. Eclogae Geologicae Helvetiae 58, 232-318.

Laubscher, H.P. 1973: Alpen und Plattentektonik. Das Problem der Bewegungsdiffusion an kompressiven Plattengrenzen. Zeitschrift der Geologischen Gesellschaft 124, 295-308.

Laubscher, H.P. and Bernoulli, D. 1982: History and deformation of the Alps. In: Hsü, K. J. (Eds.): Mountain building processes. Academic Press, London, 169-180.

Le Pichon, X., Bergerat, F. \& Roulet, M.-J. 1988: Plate hinematics and tectonics leading to the Alpine belt formation; A new analysis. Geological Society of America Special Paper 218, 111-131.

Liati, A., Froitzheim, N. \& Fanning, C.M. 2005: Jurassic ophiolites within the Valais domain of the Western and Central Alps: geochronological evidence for re-rifting of oceanic crust. Contribution to Mineralogy and Petrology 149, 446-461.

Liati, A. \& Froitzheim, N. 2006: Assessing the Valais ocean, Western Alps: $\mathrm{U}-\mathrm{Pb}$ SHRIMP zircon geochronology of eclogite in the Balma unit, on top of the Monte Rosa nappe. European Journal of Mineralogy 18, 299-308.

Löw, S. 1987: Die tektono-metamorphe Entwicklung der Nördlichen AdulaDecke (Zentralalpen, Schweiz). Beiträge zur Geologischen Karte der Schweiz [NF], 161, 84 p.

Mahlen, N.J., Skora, S., Johnson, C.M., Baumgartner, L.P., Lapen, T.J., Beard, B.L. \& Pilet, S. 2005: Lu-Hf geochronology of eclogites from Pfulwe, Zer- 
matt-Saas ophiolite, Western Alps, Switzerland. Abstract in Supplement to Geochimica and Cosmochimica Acta 69/10, 305.

Malavieille, J., Lacassin, R. \& Mattauer, M. 1984: Signification tectonique des linéations d'allongement dans les Alpes occidentales. Bulletin de la Société géologique de France 26, 895-906.

Mancel, P. \& Merle, O. 1987: Kinematics of the northern part of the Simplon Line (Central Alps). Tectonophysics, 135, 265-275.

Mancktelow, N. S. 1985: The Simplon Line: A major displacement zone in the western Lepontine Alps, Eclogae Geologicae Helvetiae 78, 73-96.

Mancktelow, N. S. 1990: The Simplon Fault Zone. Beiträge zur Geologischen Karte der Schweiz [N.F.] 163.

Mancktelow, N. S. 1992: Neogene lateral extension during convergence in the Central Alps: Evidence from interrelated faulting and backfolding around the Simplonpas (Switzerland). Tectonophysics 215, 295-317.

Marchant, R.H. \& Stampfli, G.M. 1997: Subduction of continental crust in the Western Alps. Tectonophysics 269, 217-235.

Marchant, R., Steck, A., Escher A., Levato, L., Masson, H., Olivier, R., Stampfli, G. \& Wagner, J.J. 1993: An interpretation of the deep seismic lines from the Penninic Alps of Valais (Switzerland). Bulletin de la Société géologique de France 164, 395-414.

Markley, M.J., Teyssier, C., Cosca, M.A., Caby, M.A., Hunziker, J.C. \& Sartori, M. 1998: Alpine deformation and 40Ar/39Ar geochronology of syncinematic white mica in the Siviez-Mischabel Nappe, western Pennine Alps, Switzerland. Tectonics 17, 407-425.

Masson, H. 2002: Ophiolites and other (ultra)basic rocks from the West-Central Alps: new data for a puzzle. Bulletin de la Société Vaudoise de Sciences Naturelles 88, 263-276.

Masson, H. 2006: Age carbonifère des ophiolites du Versoyen et consequences pour la géodynamique des Alpes occidentals. Geologie Alpine. Abstract volume.

Masson. H., Bussy, F., Eichenberger, M., Giroud, N., Meilhac, C. \& Presniakov, S. 2008: Early Carboniferous age of the Versoyen ophiolites and consequences: non-existence of a "Valais ocean" (Lower Penninic, Western Alps). Bulletin de la Société Géologique de France 174/4, in press.

Maurer, H., Burkhard, M., Deichmann, N. \& Green, A.G. 1997: Active Tectonism in the Western Swiss Alps. Terra Nova 9, 91-94.

Maxelon, M. \& Mancktelow, N.S. 2005: Three-dimensional geometry and tectonostratigraphy of the Pennine zone, Central Alps, Switzerland and Northern Italy. Earth-Sciences Reviews 71, 171-227.

Menard, G. 1988: Structure et cinématique d'une chaîne de collision - les Alpes occidentales et centrales. Thèse, Université Joseph Fourier de Grenoble.

Merle, O. \& Ballèvre, M. 1992: Late Cretaceous-early Tertiary detachment fault in the Western Alps. Comptes Rendus de l'Académie de Sciences de Paris 315, II, 1769-1776.

Merle, O., Cobbold, P.R. \& Schmid, S. 1989: Tertiary kinematics in the Lepontine dome. In: M.P. Coward, D. Dietrich \& R.G. Park (Eds.): Alpine Tectonics. Geological Society Special Publication 45, 113-134.

Merle, O., Le Gal, P. \& Mancel, P. 1986: Déformation et métamorphisme dans la région du Simplon (Alpes centrales). Eclogae Geologicae Helvetiae 79, 705-718.

Meyre, C., Marquer, D., Schmid, S.M. \& Ciancaleoni, L. 1998: Syn-orogenic extension along the Forcola fault: Correlation of Alpine deformations in the Tambo and Adula nappes (Eastern Penninic Alps). Eclogae Geologicae Helvetiae 91, 409-420.

Milnes, A.G. 1973: Structural re-interpretation of the classic Simplon tunnel section of the Central Alps. Bull. Geol. Soc. America, 84 269-274.

Milnes, A. G. 1974: Post-nape folding in the western Lepontinalps. Eclogae Geologicae Helvetiae 67, 333-348.

Milnes, A. G. 1975: On Steep Isogradic Surfaces in the Simplon Area: a Discussion. Contribution to Mineralogy and Petrology 53, 65-68.

Milnes, A.G., Greller, M. \& Müller, R. 1981: Sequence and style of major postnappe structures, Simplon-Pennine Alps. Journal of structural Geology 3/4, 411-420.

Milnes, A.G. \& Pfiffner, A. 1977: Structural development of the Infrahelvetic complex, eastern Switzerland, Eclogae Geologicae Helvetiae 70, 83-95.

Nagel, T., De Capitani, Ch., Frey, M., Froitzheim, N., Stünitz, H. \& Schmid, S.M. 2002: Structural and metamorphic evolution during rapid exhumation in the Lepontine dome (southern Simano and Adula nappes, Central Alps, Switzrerland). Eclogae Geologicae Helvetiae 95, 301-321.

Niggli, E. \& Niggli, C. 1965: Karten der Verbreitung einiger Mineralien der Alpidischen Metamorphose in den Schweizer Alpen (Stilpnomelan, Alkali-Amphibol, Chloritoid, Staurolith, Disthen, Sillimanit). Eclogae Geologicae Helvetiae 58, 335-368.

Oberhänsli, R., Hunziker, J., Martinotti, G. \& Stern, W.B. 1985: Geochemistry, geochronology and petrology of Monte Mucrone: an example of eo-Alpine eclogitization of Permian granitoids in the Sesia Lanzo zone, Western Alps. Chemical Geology 52,165-184.

Oberhänsli, R. \& Goffé, B. 2004: Explanatory notes to the map: Metamorphic structure of the Alps-Introduction. Mitteilungen der Österreichischen Mineralogischen Gesellschaft 149, 115-123.

Oberli, F., Meier, M., Berger, A. Rosenberg, C. \& Gieré, R. 2004: U-Th-Pb and $230^{\mathrm{Th}} / 238 \mathrm{U}$ disequilibrium isotope systematics: precise accessory mineral chronology and melt evolution tracing in the Alpine Bergell Intrusion. Geochimica et Cosmochimica Acta 68, 2543-2560.

Pavoni, N., Maurer, H., Roth, Ph. \& Deichmann, N. 1997: Seismicity and seismotectonics of the Swiss Alps. In: Pfiffner, O.A., Lehner, P., Heitzmann, P., Mueller, S. \& Steck, A. (Eds.): Deep structure of Swiss Alps: Results of NRP 20, 241-250, Birkhäuser Verlag, Basel.

Pawlig, S. \& Baumgartner, L. 2001: Geochemistry of a talc-kyanite-chloritoid shear zone within the Monte Rosa granite, Val d'Ayas, Italy. Schweizerische Mineralogische und Petrographische Mitteilungen 81,329-346.

Pettke, T., Diamond, L.W. \& Villa, I.M. 1999: Mesothermal gold veins and metamorphic devolatilization in the northwestern Alps: The temporal link. Geology 27, 641-644.

Pfeifer, H.-R., Colombi, A., Ganguin, J., Hunziker, J.C., Oberhänsli, R. \& Santini, L. 1991: Relicts of high-pressure metamorphism in different lithologies of the Central Alps, an updated inventory. Schweizerische Mineralogische und Petrographische Mitteilungen 71, 441-451.

Platt, J.P., Lister, G.S., Cunningham, P., Weston, P., Peel, F. Baudin, T. \& Dondey, H. 1989: Thrusting and backthrusting in the Briançonnais domain of the western Alps. In: M.P. Coward, D. Dietrich \& R.G. Park (Eds.): Alpine Tectonics. Geological Socity of London Special Publication 45, 135-152.

Platt, J.P., Behrmann, J.H., Cunningham, P.C., Dewey, J.F., Helman, M., Parish, M., Shepley, M.G., Wallis, S. \& Weston P.J. 1989: Kinematics of the Alpine arc and the motion history of Adria. Nature 337, 158-161.

Pleuger, J., Froitzheim, N. \& Jansen E. 2005: Folded continental and oceanic nappes on the southern side of Monte Rosa (western Alps, Italy): Anatomy of a double collision suture. Tectonics, 24: TC413, doi: 10.1029/2004T001737.

Reddy, S.M., Wheeler, J. \& Cliff, R.A. 1999: The geometry and timing of orogenic extension: an example from the Western Italian Alps. Journal of metamorphic Geology 17, 573-589.

Preiswerk, H. 1918: Geologische Beschreibung der Lepontinischen Alpen zweiter Teil: Oberes Tessin und Maggiagebiet. Beiträge zur Geologischen Karte der Schweiz [N.F.] 26, 80 p.

Preiswerk, H. 1919: Die überkippte Tauchfalte am Campolungopass und ihre früheren Deutungen. "Heim-Festschrift", Vierteljahresschrift Naturforschende Gesellschaft Zürich, LXIV, 1-15.

Preiswerk, H., Bossard, L., Grütter, O., Niggli, P., Kündig, E., Ambühl, E. et al. 1934: Geologische Karte der Tessineralpen zwischen Maggia- und BlenioTal. Geologische Spezialkarte Nr. 116, Schweizerische Geologische Kommission.

Reinecke, T. 1998: Prograde high- to ultrahigh-pressure metamorphism and exhumation of oceanic sediments at Lago di Cignana, Zermatt-Saas Fee Zone, Western Alps. Lithos 42, 147-189.

Reinhardt, B. 1966: Monte Rosa-Zone, Sesia-Zone und Canavese im Gebiet zwischen V. d'Ossola und V. Loana (Prov. Novara). Schweizerische Mineralogische und Petrographische Mitteilungen 46, 553-678.

Reusser, E. 1987: Phasenbeziehungen im Tonalit der Bergeller Intrusion. Ph.D. thesis, ETH Zürich, 8329.

Ring, U. and Merle O. 1992: Forethrusting, backfolding, and lateral gravitational escape in the northern part of the Western Alps (Monte Rosa region). Geological Society of America Bulletin 104, 901-914.

Robyr, M. 1998: Etude géologique de la region du Gornergrat, Zermatt, Valais. Master thesis, University of Lausanne. 
Romer, R., Schärer, U. \& Steck,A. 1996: Alpine and pre-Alpine magmatism in the rootzone of the western Alps. Contribution to Mineralogy and Petrology $123,138-158$.

Rosenberg, C.L. 2004: Shear zones and magma ascent: A model based on a review of the Tertiary magmatism in the Alps. Tectonics 23, TC3002, doi:10.1029/2003TC001526.

Rosenberg, C.L., Berger, A. \& Schmid, S.M. 1995: Observations from the floor of a granitoid pluton: Interferences on the driving force of final emplacement. Geology 23, 443-446.

Rubatto, D., Gebauer, D. \& Fanning, M. 1998: Dating of pre-alpine magmatism, Jurassic ophiolites and Eocene subduction of the ZermattSaas-Fee ophiolites: implications for the geodynanic evolution of the Central and Western Alps. Contribution to Mineralogy and Petrology 132, 269-287.

Rubatto, D., Gebauer, D. \& Compagnoni, R. 1999: Dating of eclogite facies zircons: the age of alpine metamorphism in the Sesia-Lasnzo zone (Western Alps). Earth and Planetary Science Letters 167,141-158.

Ruffet, G., Gruau, G., Ballèvre, M., Féraud, G. \& Philippot, P. 1997: Rb-Sr and ${ }^{40} \mathrm{Ar}-{ }^{39} \mathrm{Ar}$ laser probe dating of high-pressure phengites from the Sesia zone (Western Alps): underscoring of excess argon and new age constraints on the high-pressure metamorphism. Chemical Geology 141,1-18.

Sartori, M. 1987: Structure de la zone du Combin entre les Diablons et Zermatt (valais). Eclogea Geologicae Helvetiae 80/3, 189-814.

Sartori, M. 1993: Une carte des décrochements dans la vallée du Rhône. In: N. Mancktelow (Eds.): Schweizer Tektoniker Treffen, Zürich, Lecture Abstracts.

Schärer, U., Cosca, M., Steck, A. \& Hunziker, J. 1996: Termination of major ductile strike-slip shear and differential cooling along the Insubric line (Central Alps). Earth and Planetary Science Letters 142,331-351.

Schardt, H. 1903: Note sur le profil géologique et la tectonique du massif du Simplon compares aux travaux antérieurs. Eclogae Geologicae Helvetiae $8,173-200$

Schmid, S., Aebli, H.R. Heller, F. \& Zingg, A. 1989: The role of the Periadriatic Line in the tectonic evolution of the Alps. In: M.P. Coward, D. Dietrich \& R.G. Park (Eds.): Alpine Tectonics. Geologiacal Society of London Special Publication 45, 153-171.

Schmid, S.M., Fügenschuh, B., Kissling, E. \& Schuster, R. 2004: Tectonic map of the Alps. Eclogae Geologicae Helvetiae 97, 93-117.

Schmid, S.M., Berger, A., Davidson, C., Giere, R., Hermann, J., Vievergelt, P., Puschnig, A.R. \& Rosenberg, C. 1996: The Bergell pluton (Southern Switzerland, Northern Italy): overview accompagnying a geological-tectonic map of the intrusion and surrounding country rocks. Schweizerische Mineralogische und Petrographische Mitteilungen 76, 329-355.

Schmid, S.M. \& Kissling, E. 2000: The Arc of the western Alps in the light of geophysical data on deep crustal structure. Tectonics 19, 62-85.

Schmidt, C. \& Preiswerk, H. 1905: Geologische Karte der Simplongruppe. Beiträge zur Geologischen Karte der Schweiz, [N.F.] 26, Spezialkarte No. 48 .

Sharp, Z.D., Masson, H. \& Lucchini, R. 2005: Stable isotope geochemistry and formation mechanisms of quartz veins; Extreme paleoaltitudes of the Central Alps in the Neogene. American Journal of Science 305, $187-219$.

Soom, M.A. 1990: Abkühlung- und Hebungsgeschichte der Externmassive und der penninischen Decken beidseits der Simplon-Rhone-Linie seit dem Oligozän: Spaltspurdatierungen an Apatit/Zirkon und K-Ar-Datierungen an Biotit/Muskowit (Westliche Zentralalpen). Ph.D. Thesis, Univ. Bern.

Spicher, A. 1972: Tektonische Karte der Schweiz, 1:500'000. Schweizerische Geologische Kommission, Basel.

Stampfli, G.M., Mosar, J., Favre, P., Pillevuit, A. \& Vannay, J.-C. 2001: PermoMesozoic evolution of the western Tethys realm: the Neo-Tethys East Mediterranean basin connection. In: P.A. Ziegler, W. Cavazza, A.H.F. Robertson \& S. Crasquin-Soleau (Eds.): Peri-Tethys Memoir 6: PeriTethyan Rift/Wrench basins and passive margins. Mémoires du Museum Natninal d'Histoire Naturelle, Paris 186, 51-108.

Steck, A. 1980: Deux directions principales de flux synmétamorphiques dans les Alpes centrales. Bulletin de la Société vaudoise de Science naturelle (358), 75, 141-149.
Steck, A. 1984: Structures de déformations tertiaires dans les Alpes centrales (transversale Aar-Simplon-Ossola). Eclogae Geologicae Helvetiae 77, 55-100.

Steck, A. 1987: Le massif du Simplon - Réflexions sur la cinématique des nappes de gneiss. Schweizerische Mineralogische und Petrographische Mitteilungen 67, 27-45.

Steck, A. 1990: Une carte des zones de cisaillement ductile des Alpes Centrales. Eclogae Geologicae Helvetiae 83, 603-627.

Steck, 1998: The Maggia cross-fold: An enigmatic structure of the Lower Penninic nappes of the Lepontine Alps. Eclogae Geologicae Helvetiae 91, 333-343.

Steck, A. and Burri, G. 1971: Chemismus und Paragenesen von Granaten aus Granitgneisen der Grünschiefer- und Amphibolitfazies der Zentralalpen. Schweizerische Mineralogisch und Petrographische Mitteilungen 51, in Bericht über die 46. Hauptversammlung in Fribourg, 1-4.

Steck, A., Epard, J.L., Escher, A., Marchant, R., Masson, H. and Spring, L. 1989: Coupe tectonique horizontale des Alpes centrales. Mémoires de géologie (Lausanne) 5.

Steck, A., Epard, J.-L., Escher, A., Lehner, P., Marchant, R. \& Masson, H. 1997: Geological interpretation of the seismic profiles through Western Switzerland: Rawil (W1), Val d'Anniviers (W2), Mattertal (W3), Zmutt-Zermatt-Findelen (W4) and Val de Bagnes (W5). In: Pfiffner, O.A., Lehner, P., Heitzmann, P., Mueller, S. \& Steck, A. (Eds.): Deep structure of Swiss Alps: Results of NRP 20, 241-250, Birkhäuser Verlag, Basel.

Steck, A., Bigioggero, B., Dal Piaz, G.V., Escher, A., Martinotti, G. \& Masson, H. 1999: Carte géologique des Alpes de Suisse occidentale, 1:100 000, Carte géologique spéciale $\mathrm{N}^{\circ} 123$. Service Hydrologique et Géologique National (Berne).

Steck, A., Epard, J.-L., Escher, A., Gouffon, Y. \& Masson, H., 2001. Notice explicative de la Carte géologique des Alpes de Suisse occidentale 1:100000. Carte géologique spéciale $\mathrm{N}^{\circ} 123$. Office federal des Eaux et de la Géologie (Berne).

Steck, A., Ramsey, J.G., Milnes, A.G., \& Burri, M. 1979: Compte rendu de l'excursion de la Société Géologique Suisse et la Société de Minéralogie et Pétrographie en Valais et en Italie nord du 2 au 5 octobre 1978. Eclogae Geologicae Helvetiae 72/1, 287-311.

Steck, A. \& Hunziker, 1994: The Tertiary structural and thermal evolution nof the Central Alps - compressional and extensional structures in an orogenic belt. Tectonophysics 238, 229-254.

Steck, A. \& Tièche, J.-C. 1976: Carte géologique de l'antiforme pérdotitique de Finero avec observations sur les phases de deformation et de recristallisation. Schweizerische Mineralogische und Petrographische Mitteilungen, 141-149.

Stern, W.B. 1966: Zur Mineralchemie von Glimmern aus Tessiner Pegmatiten. Schweizerische Mineralogische und Petrographische Mitteilungen 46, 137-188.

Streckeisen, A \& Wenk, E., with a contribution by Frey, M. 1974: On Steep Isogradic Surfaces in the Simplon Area. Contribution to Mineralogy and Petrology 47, 81-95.

Stucki, A., Rubatto, D., \& Trommsdorff, V. 2003: Mesozoic ophiolite relics in the Southern Steep Belt of the Central Alps. Schweizerische Mineralogische und Petrographische Mitteilungen 83, 285-299.

Studer B. 1851: Geologie der Schweiz. Stämpflische Verlagshandlung Bern und Friedrich Schulthess Zürich.

Surace, I.R., 2004: Evénements et deformations tardi-métamorphiques dans le segment Ossola-Ticino (Val Vigezzo-Centovalli, Italie-Suisse). Ph.D. thesis, Université de Lausanne.

Tapponnier, P. 1977: Evolution tectonique du système alpin en Méditerranée: poinçonnement et écrasement rigide-plastique. Bulletin de la Société géologique de France 19, 437-460.

Tischler, M., 2005: Kinematics of the Centovalli-Line. Simplon - Val d'Ossola Excursion Guide, Swiss Tectonic Studies Group, 20-22 october 2005.

Tricart, P. 1984: From passive margin to continental collision: a tectonic scenario for the western Alps. American Journal of Science 284, 97-120.

Trommsdorff, V. 1972: Change in T-X during metamorphism of siliceaous dolomite rocks of the Central Alps. Schweizerische Mineralogische und Petrographische Mitteilungen 52,567-571. 
Trommsdorff, V. 1990: Metamorphism and tectonics of the Central Alps: The Alpine lithospheric mélange of Cima Lunga and Adula. Memorie della Societa Geologica Italia 45 39-49.:

Trümpy, R. 1980: Geology of Switzerland, Wepf \& Co, Basel.

Trommsdorff, V. \& Nievergelt, P. 1983: The Bregaglia (Bergell): Iorio intrusive and its field relations. Memorie della Societa Geologica Italia 26, 55-68.

Van Den Driessche, J., Brun, J.P., Sokoutis, D. and Mulugeta, G. 1993: Extensional gneiss domes: Laboratory models. In M. Séranne and J. Malavieille (Eds.): Late orogenic extension in mountain belts. Abstract Volume. Document du BRGM 219, 200-201.

Vialon, P., Rochette, P. \& Ménard, G. 1989. Indentation and rotation in the western Alpine arc. In: M.P. Coward, D. Dietrich \& R.G. Park (Eds.): Alpine Tectonics. Geological Society of London Special Publication 45, 329-338.

Villa, I.M. \& von Blanckenburg, F. 1991: A hornblende ${ }^{39} \mathrm{Ar}-{ }^{40} \mathrm{Ar}$ age traverse of the Bregaglia tonalite (southeast Central Alps). Schweizerische Mineralogische und Petrographische Mitteilungen 71, 73-87.

Wenk, E. 1955: Eine Strukturkarte der Tessineralpen. Schweizerische Mineralogische und Petrographische Mitteilungen 53, 311-319.

Wenk, E. 1970: Zur Regionalmetamorphose und Ultrametamorphose im Lepontin. Fortschritte der Mineralogie 47, 34-51.
Wenk, E. \& Keller, F. 1969: Isograde in Amphibolitserien der Zentralalpen. Schweizerische Mineralogische und Petrographische Mitteilungen 49, 157-19.

Wenk, E. \& Wenk, H.R. 1984, Distribution of plagioclase in carbonate rocks from the Tertiary metaorphic belt of the Central Alps. Bulletin Minéralogique 107,357-368.

Wieland, H. 1966: Zur Geologie und Petrographie der Valle Isorno (Novara, Italia). Schweizerische Mineralogische und Petrographische Mitteilungen 46, 189-303.

Zingg, A., Handy, M.R., Hunziker, J.C. \& Schmid, S.M. 1990: Tectonometamorphic history of the Ivrea Zone and its relationship to the crustal evolution of the Southern Alps. Tectonophysics 182,169-192.

Zwingmann, H. \& Mancktelow, N. 2004: Timing of Alpine fault gouges. Earth Planetary Science Letters 223, 415-425.

Manuscript received August 23, 2006

Revision accepted July 7, 2008

Editorial Handling: Stefan Bucher 
Electronic supplementary material: The online version of this article (DOI: 10.1007/s00015-008-1283-z) contains 1 fold-out plate as supplementary material, which is available to authorized users.

Plate 1. Structures of the Central Alps of Switzerland, Italy and Austria. The map is compiled and modified after Geologische Karte der Schweiz, $1: 500$ '000 (2005), Steck et al. (1999, 2001), Berger \& Mercolli (2006), Carrupt (2002), Keller et al. (1980) and completed with new field data from the Vanzone anticline and the Centovalli fault. The Maggia nappe, composed of the Sambuco spoon and the Maggia syncline, form two "Klippen" above the lower Penninic Someo - Cimalunga and Antigorio and Simano nappes. $\mathrm{Br}=$ Briançonnais, $\mathrm{CB}=$ Cimes Blanches and Frilihorn units, $\mathrm{CL}=\mathrm{Centovalli}$ line, $\mathrm{MFL}=\mathrm{Malenco}-\mathrm{Forno}-\mathrm{Lizun}$ nappe, NFP = North Penninic flysch, RKG = Rote Kuh - Gampel fault, Wa = Wandfluhhorn antiformal syncline, 2 DK = Seconda zona diorito-kinzigitica; (1) Camosci nappe, Mesozoic and Paleogene sediments, Helvetic?, (2) Mesozoic and Paleogene sedimentary cover of the lower and middle Penninic nappes,

(3) Pizzo del Vallone nappe, Mesozoic and Paleogene sediments, Carrupt (2002), (4) Geisspfad serpentinite, (5) Cima d'Agaro peridotite, (6) Albogno peridotite, (7) Moncucco peridotite, (8) Finero peridotite, (9) Brusson window, (10) Canavese Permian-Liassic sediments, (11) Scaredi unit (Ivrea basement). (12) Chiavenna ophiolites, (13) Salarioli sediments, Carboniferous - Triassic, (14) Tuftgrat zone, Triassic - Paleogene (?) cover of the Stockhorn crystalline, Robyr (1998), (15) Teggiolo zone, Mesozoic cover of the Antigorio nappe, (16) Mesozoic cover of the Portjengrat unit. 